\title{
Hypoxia and Extracellular Acidification as Drivers of Melanoma Progression and Drug Resistance
}

\author{
Ewelina Dratkiewicz $^{1, *(1)}$, Aleksandra Simiczyjew ${ }^{1}$, Justyna Mazurkiewicz ${ }^{1}\left({ }^{1}\right.$, Marcin Ziętek ${ }^{2,3}{ }^{\circledR}$, \\ Rafał Matkowski ${ }^{2,3}$ and Dorota Nowak ${ }^{1}$ \\ 1 Department of Cell Pathology, Faculty of Biotechnology, University of Wroclaw, Joliot-Curie 14a, \\ 50-383 Wroclaw, Poland; aleksandra.simiczyjew@uwr.edu.pl (A.S.); \\ justyna.mazurkiewicz2@uwr.edu.pl (J.M.); dorota.nowak@uwr.edu.pl (D.N.) \\ 2 Department of Oncology and Division of Surgical Oncology, Wroclaw Medical University, Plac Hirszfelda 12, \\ 53-413 Wroclaw, Poland; zietek.m@dco.com.pl (M.Z.); rafal.matkowski@umed.wroc.pl (R.M.) \\ 3 Wroclaw Comprehensive Cancer Center, Plac Hirszfelda 12, 53-413 Wroclaw, Poland \\ * Correspondence: ewelina.dratkiewicz@uwr.edu.pl
}

check for updates

Citation: Dratkiewicz, E.; Simiczyjew, A.; Mazurkiewicz, J.; Ziętek, M.; Matkowski, R.; Nowak, D. Hypoxia and Extracellular Acidification as Drivers of Melanoma Progression and Drug Resistance. Cells 2021, 10, 862. https://doi.org/ 10.3390/cells10040862

Academic Editors: Adrian Harris and Francesco Pezzella

Received: 3 March 2021

Accepted: 7 April 2021

Published: 9 April 2021

Publisher's Note: MDPI stays neutral with regard to jurisdictional claims in published maps and institutional affiliations.

Copyright: (c) 2021 by the authors. Licensee MDPI, Basel, Switzerland. This article is an open access article distributed under the terms and conditions of the Creative Commons Attribution (CC BY) license (https:// creativecommons.org/licenses/by/ $4.0 /)$.

\begin{abstract}
Hypoxia and elevated extracellular acidification are prevalent features of solid tumors and they are often shown to facilitate cancer progression and drug resistance. In this review, we have compiled recent and most relevant research pertaining to the role of hypoxia and acidification in melanoma growth, invasiveness, and response to therapy. Melanoma represents a highly aggressive and heterogeneous type of skin cancer. Currently employed treatments, including BRAF V600E inhibitors and immune therapy, often are not effective due to a rapidly developing drug resistance. A variety of intracellular mechanisms impeding the treatment were discovered. However, the tumor microenvironment encompassing stromal and immune cells, extracellular matrix, and physicochemical conditions such as oxygen level or acidity, may also influence the therapy effectiveness. Hypoxia and acidification are able to reprogram the metabolism of melanoma cells, enhance their survival and invasiveness, as well as promote the immunosuppressive environment. For this reason, these physicochemical features of the melanoma niche and signaling pathways related to them emerge as potential therapeutic targets.
\end{abstract}

Keywords: melanoma; hypoxia; acidification; drug resistance; tumor microenvironment; immune escape; invasiveness

\section{Introduction}

Cutaneous melanoma is a very heterogeneous cancer characterized by pronounced invasive abilities and is responsible for $80 \%$ of deaths caused by skin cancer [1]. It arises from transformed neural crest-derived melanocytes, which, in physiological conditions upon UV exposure, produce the pigment melanin, and in cooperation with keratinocytes, they protect skin cells against UV-induced DNA damage [2].

While melanoma is recognized to exhibit high heterogeneity, a BRAF V600E mutation present in a gene encoding a member of the Ras/MAPK (mitogen-activated protein kinase) signaling pathway is a predominant genetic aberration detected in over $40 \%$ of melanoma patients [3,4]. Together with other specific markers, i.e., PD-L1 (programmed death ligand 1), CTLA-4 (cytotoxic T-lymphocyte-associated protein 4), this molecular feature of melanoma led to the development of targeted therapies, which improved the clinical results, so far relying on surgical excision and systemic chemo- and radiotherapy [5]. Nevertheless, melanoma continues to pose a great therapeutic challenge due to its rapidly emerging resistance to the majority of currently employed treatments [6].

Taking into account a great complexity of the melanoma microenvironment, it seems valid to consider specific factors of the tumor niche as potential therapy targets. Melanoma milieu consists of a number of cell types (e.g., keratinocytes, cancer-associated fibroblasts 
(CAFs), adipocytes, endothelial, and immune cells) and elements of extracellular matrix (ECM) [7]. It also exhibits a specific set of biophysical properties (e.g., hypoxia, acidification), which are able to influence the progression of cancer and its drug sensitivity $[8,9]$. In our previous works, we addressed the significance of crosstalk between cancer and stromal cells in melanoma growth, progression, and drug resistance $[7,10]$. Here, we endeavor to comprehensively review the most essential and recent research in the field of two closely related features of the tumor niche-hypoxia and acidification. We focus mainly on hypoxiaand acidification-induced aggressiveness and drug resistance of melanoma, as well as on novel anticancer treatment targeting these elements of the tumor microenvironment (TME).

\section{Hypoxia}

\subsection{Molecular Basis of Hypoxia}

A prevalent feature of solid tumors is a state of hypoxia, characterized by a low oxygen level $(<1 \%)$, in comparison to a physiological $\mathrm{O}_{2}$ concentration, reaching approximately $4-10 \%$, varying between different types of tissues and organs $[11,12]$. This pathological condition is a result of a dysfunctional vasculature developed upon the cancer cells' stimulatory signals, which is unable to provide a sufficient supply of oxygen to the intensively growing tumor mass, especially in the case of solid tumors (Figure 1) [13]. For skin tissue, the values of $\mathrm{O}_{2}$ concentration vary from $17.7 \%$ for the outer layers of the epidermis and down to trace concentrations for some areas of the dermis [14]. While the response of cells to hypoxia is strongly dependent on the tissue type and its initial oxygenation, the lack of $\mathrm{O}_{2}$ often leads to the cell apoptosis. Considering the adaptation of cancer cells to adverse conditions, paradoxically, hypoxia frequently supports their survival and more aggressive phenotype [11,15]. The data acquired from melanoma cancer patients indicate the positive correlation between the presence of hypoxia within the tumor mass and a poor prognosis for these patients [16].

The master regulators of a hypoxic response are proteins called hypoxia-inducible factors (HIF). The active protein capable of binding to the hypoxia response elements in the DNA sequence consists of two subunits-HIF- $\alpha$ and HIF- $\beta$ [17]. HIF- $1 \beta$ is a constitutively expressed protein located in the nucleus, while the expression level of three members of the HIF- $\alpha$ family (HIF- $1 \alpha$, HIF- $2 \alpha$, and HIF- $3 \alpha$ ) is highly dependent on the cellular oxygen concentration $[18,19]$. In the presence of $\mathrm{O}_{2}$, the PHD (prolyl hydroxylase domain protein) enzymes hydroxylate HIF- $\alpha$ molecules, which leads to their ubiquitination by the ubiquitin ligase complex recruited by the pVHL protein (von Hippel-Lindau tumor suppressor) and subsequent degradation in the proteasome. The absence of oxygen inhibits PHDs activity, promoting the stability of HIF- $\alpha$, as well as allowing for its translocation to the nucleus and dimerization with HIF-1 $\beta[20,21]$.

HIF- $1 \alpha$ can be also activated in hypoxia-independent manner in response to growth factors and cytokines stimulation, which activate signaling pathways such as Ras/MAPK, PI3K (phosphoinositide 3-kinase)/ AKT or NF- $k B$ (nuclear factor-kappa B), known to be often upregulated in cancer cells [22,23]. Additionally, epigenetic changes and mutations may influence the level and stability of this transcription factor [24].

The overexpression of HIF- $1 \alpha$ was detected in biopsies derived from patients suffering from skin cancer and uveal melanoma. It was also elevated in metastatic tissue compared to the primary tumors as well as correlated with high expression of proliferative and vascular markers $[25,26]$. A number of studies report the upregulation of HIF- $1 \alpha$ expression in a panel of primary and metastatic melanoma cell lines even in experimental normoxic conditions, which can be partially attributed to the slightly hypoxic conditions present in the normal skin tissue, especially in the lower layers of the epidermis where the melanocytes reside [14,27-29]. 


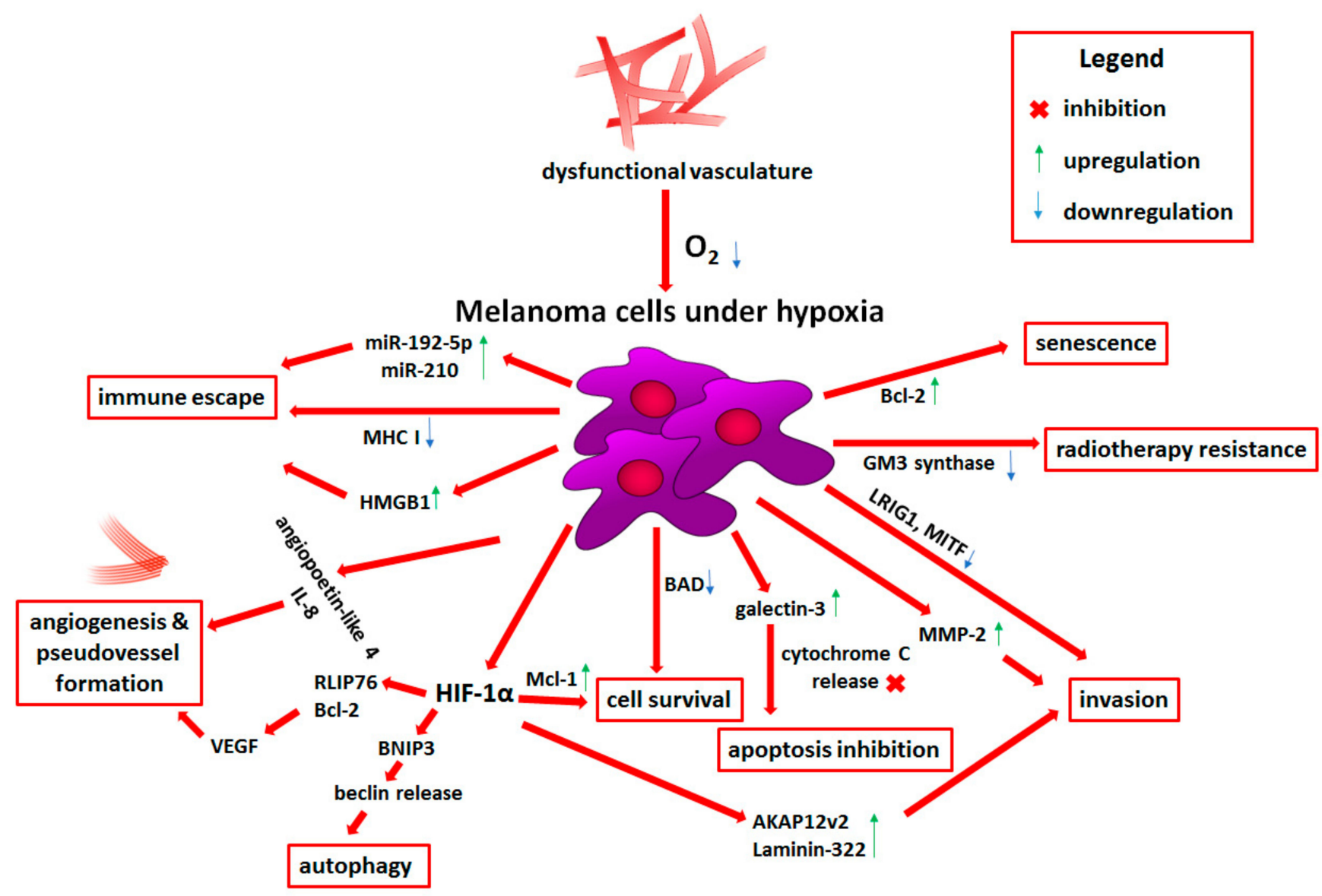

Figure 1. Influence of hypoxia on melanoma progression. Detailed descriptions can be found in the text. Abbreviations: miR, microRNA; MHC I, major histocompatibility complex class I; HMGB1, high mobility group box 1 protein; IL-8, interleukin 8; VEGF, vascular endothelial growth factor; RLIP76, Ral-interacting protein of 76 kDa; Bcl-2, B-cell CLL/lymphoma 2; BNIP3, Bcl-2 interacting protein 3; HIF-1 $\alpha$, hypoxia-inducible factor $1 \alpha$; Mcl-1, myeloid cell leukemia 1; BAD, Bcl-2-associated agonist of cell death; AKAP12v2, A-kinase anchor protein 12 variant 2; MMP2, matrix metalloproteinase 2; LRIG1, leucine-rich repeats and Ig-like domains 1 ; MITF, microphthalmia-associated transcription factor; GM-3, monosialodihexosylganglioside.

On the other hand, the role of HIF- $2 \alpha$ in melanoma was not as extensively studied and the data are often inconclusive. A positive correlation between poor prognosis and the high expression of HIF-2 $\alpha$ as well as VEGF (vascular endothelial growth factor) was observed in samples isolated from nodular malignant melanomas of the skin, while Hao et al. showed that HIF-2 $\alpha$ overexpression induced the stemness in melanoma cells through inhibition of p21 [30]. However, another study indicated that the HIF-2 $\alpha$ in a melanoma cell line model led to the reduction of these invasive abilities [31,32]. Interestingly, it was also shown that HIF-2 $\alpha$-deficient tumors exhibit increased interferon-based signaling, antigen presentation, as well as CD8+ T cell infiltration and activation [33]. These differences in HIF-2 $\alpha$-induced cellular responses may be cell- and organ-specific or stem from the temporary balance between different HIF isoforms. Less is known about the HIF-3 $\alpha$ level in skin cancers.

The expression of HIF- $\alpha$ regulating enzymes may also influence tumor aggressiveness. While hypoxia inhibits the activation of PHD2 due to the lack of oxygen required for its function, melanoma cells were shown to lose the expression of this enzyme during transition from benign nevi to melanoma. Moreover, the simultaneous presence of BRAF V600E mutation and loss of PHD2 expression in melanocytes led to their malignant transformation towards highly invasive melanoma [34]. 


\subsection{Role of Hypoxia in Melanoma Progression}

\subsubsection{Prosurvival Role of Hypoxia}

Upon the introduction of hypoxic conditions, apoptotic pathways are induced in the majority of normal cells and a population of cancer cells, which eventually leads to cell death. However, cancer cells often exhibit HIF- $1 \alpha$ stable expression and activation, which renders them resistant to the adverse microenvironment [35].

The hypoxic response may be mediated by small non-coding microRNAs (miRs), which post-transcriptionally regulate the expression of various genes. It was shown that miR-211 is able to sensitize melanoma cells to hypoxia-induced cell death, however cancer cells lose its expression during melanomagenesis, especially in hypoxic conditions [36]. Also, the upregulation of miR-302 elicits a hypoxia-related decrease in the viability of melanoma cells [37].

One of the main regulators of hypoxia-induced apoptosis is the tumor suppressor protein, p53. Leszczynska et al. identified a group of p53 proapoptotic target genes (e.g., INPP5D (inositol polyphosphate-5-phosphatase), CYFIP2 (cytoplasmic FMR1-interacting protein 2)), which, upon expression, inhibit AKT activity leading to cell death. Interestingly, downregulation of these genes, presumably as a result of hypoxia-induced mutations in the gene encoding p53, was detected in melanoma patients as well as correlated with worse prognosis [38].

It was also shown that following hypoxia exposure, melanoma cells bearing $B R A F$ $V 600 E$ mutation exhibit downregulation in the expression of genes encoding apoptotic regulators- $B A D$ (Bcl-2-associated agonist of cell death) and BCL2L1 (Bcl-2-like 1, also known as Bcl-X) [39]. While a decrease in $B A D$ expression may act antiapoptotic and promote cell survival (Figure 1), the data concerning BCL2L1 could be interpreted disparately, as the gene can give rise to two isoforms that display opposite functions [40]. The HIF- $1 \alpha$-induced overexpression of antiapoptotic protein Mcl-1 (myeloid cell leukemia 1) was also observed in BRAF-mutated melanoma cells (Figure 1). It correlated with a higher rate of resistance to anoikis, which is a form of apoptosis resulting from lack of adhesion. This ability is crucial for malignant cells to survive outside of the primary tumor site [41,42].

Furthermore, using in vitro murine melanoma model, Bacchi et al. have shown that cells exposed to hypoxia and high glucose concentration exhibit upregulated expression of galectin-3, which displays some similarities to Bcl-2 (B-cell CLL/lymphoma 2) family proteins and is also able to block apoptosis (Figure 1) [43]. However, others have reported that galectin-3 may act as a metastasis suppressor or even sensitize BRAF-mutated melanoma cells to vemurafenib (BRAF V600E inhibitor) treatment [44,45].

Additionally, Wang et al. showed that activation of hypoxic response involves overexpression of Bcl-2, which leads to a state of permanent cell arrest, so-called senescence (Figure 1) [46]. Although senescent cells do not proliferate, they still exhibit metabolic activity and are able to influence adjacent cells present in the tumor microenvironment. Hypoxia-induced secretion of MMP2 (matrix metalloproteinase 2) by senescent cells was also implicated in facilitating the invasion of melanoma cells (Figure 1) [47].

The levels of lipid raft-associated gangliosides as well as ganglioside synthesizing and processing enzymes, which are involved in the regulation of endoplasmic reticulum stress response and apoptosis, can also be influenced by hypoxia. Low oxygen levels led to the downregulation of GM3 (monosialodihexosylganglioside) synthase in melanoma cells, which produces a common precursor of gangliosides. Reduction in GM3 levels allows for elevated receptor tyrosine kinase dimerization and subsequent hyperactivation of ERK (extracellular signal-regulated kinase) kinase. This process contributed to the emergence of radiotherapy resistance, taking into account the antiapoptotic and cell cycle arrest-inducing role of ERK (Figure 1) [48,49].

Finally, cancer cells exposed to hypoxia can induce autophagy, a process responsible for maintaining cell homeostasis in a lysosome-mediated way. Activation of HIF- $1 \alpha$ stimulates BNIP3 (Bcl-2 interacting protein 3 ), which in turn releases beclin from its asso- 
ciation with Bcl-2 or Bcl-XL and leads to autophagy initiation (Figure 1) [50]. Increased level of BNIP3 was detected in melanoma cells under hypoxia, which also correlated with reduced response to anti-PD-1 (programmed cell death 1) treatment [51]. The overexpression of beclin 1 was also associated with highly pigmented and hypoxic areas of uveal melanoma tumors, which characterized patients with poor prognosis [52]. However, prolonged autophagy induced by nutrients deprivation, together with hypoxic conditions, may eventually lead to cell death [53].

\subsubsection{Angiogenesis and Vasculogenic Mimicry Induced by Low Oxygen Levels}

Hypoxia arises as a consequence of insufficient or dysfunctional vasculature in the area of intensively proliferating cancer cells. To avoid growth deceleration or even necrosis, cells trigger HIF-1-dependent pathways, which leads to the initiation of angiogenesis, where new vessels are formed from preexisting vascular networks, or results in the emergence of cancer cells-derived pseudovessels in a process called vasculogenic mimicry [54].

The main component of blood vessels are endothelial cells (ECs), which form a barrier between the conducted physiological fluids and the tissue. New vessels can be formed from preexisting ones under proangiogenic stimuli including gradient of VEGFA (vascular endothelial growth factor A), which, together with other factors, directs the vascular sprouting of motile ECs [55]. Das et al. reported the importance of communication between melanoma and endothelial cells for the survival of ECs in adverse conditions. Following exposure to melanoma conditioned medium (CM), the ECs were able to endure longterm hypoxia, while a similar result was not observed for melanocytes-derived CM. The activation of AKT and MAPK/ERK pathways was responsible for this effect [56]. It was also shown that, while mature ECs form vessel-like tubes, melanoma cells preferentially recruit ECs early progenitors to build pathological vasculature. This process is mediated by hypoxia-induced stabilization of cancer stem-like cells (CSCs), which exhibit increased activity of one of the CSC markers-ALDH (aldehyde dehydrogenase) [57].

Mutual regulation between melanoma cells and ECs under hypoxic conditions also involves functional regulators of HIF-1, which influence the angiogenic components of the cancer cell secretome including endothelin-1 and RLIP76 (Ral-interacting protein of $76 \mathrm{kDa}$ ) signaling, which in turn activate HIF-mediated VEGFA and VEGFC expression. Moreover, melanoma cells treated with conditioned medium derived from ECs were more prone to form vessel-like channels (Figure 1) [58,59]. Another protein involved in the regulation of endothelial cell tubes formation through the activation of VEGFA expression is DRG2 (developmentally regulated GTP-binding protein 2), which participates in the HIF-1 $\alpha$ translocation to the nucleus. It was also shown that DRG2 expression correlates with poor survival of melanoma patients and was more pronounced in metastatic compared to primary tumors [60]. Interestingly, previously mentioned antiapoptotic protein Bcl-2, following its relocation to the nucleus, is also able to induce VEGF expression in HIF-1dependent way [61].

Elevated expression of VEGF and HIF-1 $\alpha$ in correlation with vascularity in uveal melanoma patients was also observed. Moreover, hypoxic uveal melanoma cells exhibited increased angiopoietin-like 4 expression, which inhibition in vitro and in vivo reduced angiogenic potential of these cells (Figure 1) [62]. VEGF expression was also detected along vessel-like channels in specimens from choroidal melanoma patients, which originated as a result of the vasculogenic mimicry. Hypoxia was responsible for VEGF expression upregulation and subsequently for PI3K/AKT-mediated development of pseudovessels [63].

High level of another proangiogenic molecule, IL-8 (interleukin 8), was detected in samples collected from melanoma patients representing different stages of cancer (Figure 1). Additionally, upregulation of IL-8 correlated with the elevated expression of multicellular (e.g., endothelial and hematopoietic stem cells) CD34 antigen, and together they were associated with worse prognosis [64]. Similarly, Timani et al. linked hypoxia-driven IL-8 upregulation and poor prognosis of melanoma patients to reduced expression of a multifaceted nuclear protein, Tip110 [65]. Elevated level of IL-8 and VEGF following GRM1 
(metabotropic glutamate receptor 1)-dependent activation of AKT/mTOR (mechanistic target of rapamycin)/HIF-1 axis was also found in media derived from melanoma cells, while inhibition of GRM1 in melanoma patients led to the reduction of vasculature density in tumor specimens [66]. Melanoma cells, however, are not the only source of proangiogenic factors in the tumor microenvironment (TME). Activated fibroblasts (also called CAFs), which may constitute even $80 \%$ of the tumor mass, when exposed to hypoxia, also secrete elevated level of VEGFA and IL-6 compared to the cells cultured in normoxia $[67,68]$.

\subsubsection{Melanoma Plasticity and Invasiveness under Hypoxia}

Hypoxia has been repeatedly correlated with highly aggressive cancer phenotype and worse prognosis for patients [15]. This aggressiveness is often associated with elevated plasticity of tumors, which exhibit potent invasive abilities.

The master regulator of melanocyte development and a more proliferative cancer phenotype is MITF (microphthalmia-associated transcription factor), which expression is distinctive for melanoma-initiating cells. Its downregulation is often indicative of transcriptional reprogramming resulting in the emergence of a migratory phenotype $[69,70]$. Indeed, hypoxia exposure of melanocytes harboring KIT mutations led to the reduction of MITF expression and their malignant transformation (Figure 1) [71]. Widmer et al. also noted a loss of melanocytic markers in melanoma biopsies, which correlated with hypoxic regions [72]. Furthermore, melanocytes exposed to low oxygen levels underwent downregulation of anti-metastatic and antiangiogenic molecule-PEDF (pigment epithelium-derived factor). Loss of PEDF expression was associated with the acquisition of an invasive phenotype by transformed cells [73].

Hypoxia may also induce the selection of cancer stem-like cells, which exhibit a selfrenewal ability, increased invasiveness, and elevated drug resistance. Nodal, one of the regulators of cell stemness, was shown to be induced following hypoxia exposure, and its increased expression correlated with a more aggressive and resistant melanoma phenotype. Inhibition of Nodal expression partially sensitizes cells to chemotherapy, confirming its role in the development of drug resistance [74].

High aggressiveness of melanoma cells may also result from the induction of epithelialto-mesenchymal transition (EMT), during which cells lose their epithelial polarity and intercellular junctions in favor of a mesenchymal phenotype allowing them to invade through the tissues. It was shown that hypoxia reduced the expression of LRIG1 (leucinerich repeats and Ig-like domains protein 1), a negative regulator of ERBB receptors, which led to the activation of EGFR (epithelial growth factor receptor)/ERK signaling and induction of EMT (Figure 1). It was also accompanied by an elevated rate of migration, invasion, and vasculogenic mimicry. Erlotinib, a specific inhibitor of EGFR, was able to abrogate invasive abilities of LRIG1-devoid cells under hypoxia, of which observation may help in the development of anti-melanoma therapies [75].

EMT process, as well as ERK/AKT-mediated invasion, can be activated by Notch signaling, which is also promoted by low oxygen level [76,77]. Liu et al. indicated that the hypoxic response is mediated by Snail1, one of the main transcriptional regulators of EMT. Hypoxia led to the elevated expression of mesenchymal markers (Snail1, N-cadherin (neuronal cadherin), $\alpha$-SMA ( $\alpha$-smooth muscle actin), SOX10 (SRY-box transcription factor 10)) with simultaneous reduction in E-cadherin (epithelial cadherin) level in melanoma cells. Additionally, cells exposed to low oxygen concentration demonstrated higher resistance to chemotherapy, including cisplatin and temozolomid treatment [78].

Increased invasiveness of melanoma cells was also reported following treatment with conditioned media derived from activated fibroblasts cultured in hypoxia [68,79]. This process could be mediated by molecules secreted by CAFs-SDF-1 (stromal cell-derived factor-1) and IL-6. SDF-1 was also shown to induce EMT in uveal melanoma cells, while IL6 is able to promote cell motility through upregulation of WNT5A (wingless-type mammary tumor virus integration site family member 5A) expression [68,80,81]. 
Several reports also indicate the role of hypoxia in the expression of cytoskeleton regulating proteins and subsequently in melanoma invasive abilities. The formation of migratory protrusions and focal adhesions is governed by prominent members of the Rho GTPase family - RhoA (Ras homolog family member A), Rac1 (Rac family small GTPase 1), and Cdc42 (cell division cycle 42) [82]. An elevated HIF-1 $\alpha$ level was associated with increased expression and activation of RhoA, as well as higher migratory potential of HT168-M1 melanoma cell line [83]. Stimulation of another member of the small GTPase family, Rab5, which is involved in focal adhesion dynamics, migration, and Rac1 activation, was also facilitated by low oxygen levels. Hypoxia promoted re-localization of Rab5 to the cell leading edge and its association with focal adhesions, as well as FAK (focal adhesion kinase) phosphorylation and hypoxia-driven melanoma cell migration [84].

The transduction of signals between the cell surface and cytoskeleton is regulated by scaffold proteins which act as a binding-platform for kinases and other actin-associated proteins. HIF- $1 \alpha$-induced expression of AKAP12v2 (A-kinase anchor protein 12 variant 2) was shown to promote migration and invasion of melanoma cells (Figure 1) [85]. Annexin A3 also plays a role in actin-based signal transduction. Xu et al. noted an elevated level of this protein in melanoma patients, while downregulation of annexin A3 reduced migratory abilities of melanoma cells in HIF-1 $\alpha$ /VEGF-dependent manner [86].

The interaction of cancer cells with the extracellular matrix is essential in a number of processes, including adhesion, migration, and invasion. This interplay is governed by surface proteins that act as receptors for soluble ligands or as scaffolds for the ECM molecules present in the extracellular space [87]. Dahl et al. reported that the exposure to hypoxia was responsible for elevated level of $\alpha_{V} \beta_{3}$ integrin and increased adhesion to vitronectin in a metastatic murine melanoma model [88]. It was also demonstrated that HIF- $1 \alpha$ is able to upregulate the expression of laminin-322, one of the main ECM elements secreted by keratinocytes, which was shown to promote adhesion and migration of melanoma cells (Figure 1) $[89,90]$. There are reports indicating that syndecans, proteoglycans responsible a.o. for the ECM organization, are involved in the dysregulation of the TME. CAFs exhibited an elevated level of syndecan-4, while high expression of syndecan-3 was detected in melanoma cells, epithelial cells, and tumor-associated macrophages, which also correlated with hypoxia gene signature [91]. Finally, hypoxia is known to upregulate LOX (lysyl oxidase), one of the enzymes responsible for collagen crosslinking. LOX activity was shown to promote cancer metastasis and formation of pre-metastatic niches [76,87].

Cancer invasiveness can be further regulated by microRNAs. Downregulation of several miRs (e.g., miR-224-5p, miR-23a-5p, mi-23b-5p) with simultaneous upregulation of miR-1290 levels correlated with elevated invasive abilities of melanoma cells [92-94]. In the case of melanoma, the exact effect of FXR2 (fragile X mental retardation syndrome-related protein 2) expression regulation by miR-1290 is still poorly understood [95]. However, it was shown that the depletion of FXR2 homolog-FXR1—in melanoma led to impaired invasion and metastasis [96,97].

\subsubsection{Metabolic Reprogramming Induced by Low Oxygen Level}

The principal metabolic strategy of human cells relies on oxygen. To produce energy, cells employ so called oxidative phosphorylation (OXPHOS), which takes place in the mitochondria. Hypoxic conditions are responsible for metabolic reprogramming of cancer cells, which start to favor glycolysis and subsequent lactic fermentation, a shift also characterizing Warburg effect [98].

Koch et al. showed that melanoma cells exposed to low oxygen concentration exhibited a highly glycolytic phenotype, including elevated expression of GLUT1 (glucose transporter isoform 1), HK2 (hexokinase 2), and LDH-A (lactate dehydrogenase A). Furthermore, BRAF-mutated cells demonstrated increased GLUT1 levels and invasive abilities in hypoxic conditions [99]. Another enzyme involved in glycolysis, PFKFB4 (6-phosphofructo2-kinase/fructose-2,6-biphosphatase 4), was also demonstrated to be upregulated following exposure to hypoxia and its high expression correlated with poor prognosis of melanoma 
patients [100]. Zhuo et al. have also observed upregulation of GLUT1 and HK2 expression, as well as elevated lactate production and reduced mitochondrial content consistent with cancer cells glycolytic shift in a melanoma model in vitro. Interestingly, they also noted decreased sensitivity of the examined cell lines to cisplatin and doxorubicin upon hypoxia exposure [101].

Increased activity of LDH-A also leads to a change in metabolites' balance-there is less $\alpha$-ketoglutarate $(\alpha-\mathrm{KG})$ produced than L-2-hydroxyglutarate. On the one hand, together with the low supply of glutamine in the tumor microenvironment, which is essential for $\alpha-K G$ production, it leads to the reduced activity of demethylases using $\alpha-K G$ as a co-substrate. On the other hand, L-2-hydroxyglutarate may act as an inhibitor of these enzymes. Low activity of demethylases results in accumulation of aberrations in the methylation of histones (e.g., H3K27me3), DNA, and RNA, further inducing drug resistance and heterogeneity of patient-derived BRAF-mutated melanoma cells [102,103].

Another regulator of decreased mitochondrial metabolism is pyruvate dehydrogenase kinase 4 (PDK4). It phosphorylates pyruvate dehydrogenase, which in turn leads to reduced OXPHOS, and thus lowered oxygen use, resulting in HIF- $1 \alpha$ stabilization. PDK4 is a target gene of miR-211, which expression is lost during melanoma malignant transformation. This small non-coding RNA acts as a metabolic switch, allowing cancer cells to survive during hypoxia [36].

The tricarboxylic acid (TCA) cycle, which in normoxia is tightly linked to glycolysis through the production of acetyl-CoA from pyruvate, in hypoxic conditions starts to run in reverse to maintain cell proliferation. In this case, glutamine acts as a main carbon source for acetyl-CoA, citrate, and fatty acids. Additionally, BRAF- and NRAS-mutated melanoma cells exhibit elevated utilization of this amino acid as a substrate for fatty acid biosynthesis [104]. One of the TCA cycle intermediates, succinate, revealed its role as a HIF$1 \alpha$ stabilizing agent, as it inhibits PHD2, an enzyme responsible for HIF- $1 \alpha$ degradation. Interestingly, this process is partially regulated by MITF [105].

\subsubsection{Hypoxia-Dependent Immune Escape}

Cancer cells also utilize survival strategies, which rely on suppression of the organism immune response against malignantly transformed cells. Hypoxia may enhance the antitumor immune cell function. However, usually a low oxygen level in the tumor niche promotes recruitment of immunosuppressive cells (e.g., Tregs (T regulatory cells), MDSCs (myeloid-derived suppressor cells), M2 macrophages) and secretion of proinflammatory cytokines (e.g., IL-10), as well as leads to reduced cytotoxic activity of NK (natural killer) and T cells $[106,107]$.

CD8+ cytotoxic T cells (CTLs), upon recognition of antigen presented by other cells, induce cancer cell death via release of granzymes, perforin, etc. [108]. In the case of tumors, to accomplish their immunogenic task, CTLs need to leave the vasculature and come in direct contact with cancer cells. Indeed, the accumulation of CD8+ cells occurred around the peripheral blood vessels in the samples derived from melanoma patients' biopsies. Additionally, reduced number of tumor-infiltrating CTLs correlated with a worse prognosis. In vitro studies have shown that the diminished motility of immune cells towards the tumor mass may result from hypoxia and decreased rate of OXPHOS [109]. Marijt et al. observed that hypoxia together with glucose-deprivation impaired antigen presentation via MHC (major histocompatibility complex) class I and subsequent recognition by CTLs, even in the presence of the stimulatory cytokine IFN $\gamma$ (interferon $\gamma$ ) [110]. Loss of sensitivity to IFN treatment as a result of HIF-1 $\alpha /$ RIG-I (retinoic acid-inducible gene I)-dependent downregulation of IFN $\alpha \mathrm{R}$ (interferon $\alpha$ receptor) expression and consequent diminished NK- and CTL-mediated cell death was also observed in human and murine melanoma cells [111].

Reduced cytotoxic activity of CTLs against cancer cells could also stem from HIF- $1 \alpha$ driven decreased expression of MHC class I on the surface of tumor cells, as well as be associated with tumor-protective role of extracellular adenosine (Figure 1). Hypoxia was 
shown to upregulate the expression of adenosine producing enzymes (CD39, CD73), which in turn contribute to elevated adenosine and adenosine receptor levels, followed by activation of CREB (cAMP-response element binding protein)-mediated immune suppression via proinflammatory molecules expression (e.g., IL-2, IL-6, IL-10) [112,113]. The adenosineinduced signaling may result in inhibition of macrophage activation and NK cell infiltration, as well as severely changed $\mathrm{T}$ cell profiles. It leads to the reduction of antitumoral effector $\mathrm{T}$ cell proliferation, maturation, terminal differentiation, migration, and finally their cytotoxic activity, with a simultaneous increase in T cell switch towards an immunosuppressive Tregs lineage, partially supported by an upregulation in CTLA-4 expression $[114,115]$.

Suppression of CTL cytotoxic activity may be also mediated by miR-192-5p produced by melanoma cells under hypoxic conditions, which is then transported to immune cells through connexin-43-constituting gap junctions of cancer cells [116]. Moreover, hypoxiainduced miR-210 expression disturbs melanoma sensitivity to $\mathrm{T}$ cell lysis, through the inhibition of genes known to influence this process (PTPN1 (protein tyrosine phosphatase non-receptor type 1), HOXA1 (homeobox A1), TP53I11 (tumor protein P53-inducible protein 11)) (Figure 1) [117,118].

On the other hand, Kajiwara et al. noted that murine melanoma cells pre-incubated in hypoxia elicit greater antigen-specific CTL response compared to cells growing in normoxia. This process was facilitated by upregulation of MHC class I mediated by ERO1 $\alpha$ (endoplasmic reticulum oxidoreductase $1 \alpha$ ) activity, one of the enzymes responsible for the formation of disulfide bonds in the polypeptide chain [119]. Finally, CTLs used in anticancer therapy are usually cultured in normoxia, while the targeted tumor resides in hypoxic conditions. It was shown that pre-incubation of CTLs in hypoxia improves their ability to kill malignant cells, possibly due to minor changes in the composition of the cytotoxic granules [120].

Stress-related catecholamines, i.e., adrenaline and noradrenaline, which interact with $\beta$-adrenoreceptors, were also shown to promote melanoma progression and metastasis. Following exposure to hypoxia, the upregulation of $\beta_{3}$-adrenoreceptors was noted in immunosuppressive peripheral blood mononuclear cells (NK cells, MDSCs, and Tregs). Application of $\beta$-blockers (e.g., propranolol) led to the attenuation of immunosuppressive cell subpopulations, as well as improved the number of cytotoxic immune cells (NK, CTLs) within the TME. Inhibition of hypoxia-induced $\beta_{3}$-adrenoreceptors also promoted M1 polarization of macrophages, reducing the rate of M2 type, a phenotypic shift associated with immune suppression [121].

The ability of cancer cells to recruit immunosuppressive cells or re-educate them towards pro-tumoral phenotype is often dependent on paracrine signaling. For instance, uveal melanoma cells exposed to hypoxia produced an assortment of proinflammatory molecules (e.g., plasminogen, TGF $\beta$ (transforming growth factor $\beta$ ), endothelin 1 ) and the tumor cell-derived conditioned medium was able to inhibit the differentiation of dendritic cells [122]. The recruitment of M2 macrophages in a hypoxia-dependent manner was observed in VEGF- and HMGB1 (high mobility group box 1)-secreting melanoma cells (Figure 1) $[123,124]$. Stimulated M2 macrophages subsequently generated great amounts of proinflammatory IL-10. Furthermore, melanoma patients with diagnosed metastatic tumor exhibited elevated serum concentration of HMGB1 [124]. Yang et al. have shown that low oxygen concentration in the tumor microenvironment leads to downregulation of MHC class II expression in tumor-associated macrophages, priming their shift towards an M2 phenotype [125].

\subsubsection{Reduced Therapy Efficiency and Novel Hypoxia-Targeted Treatment Strategies}

The adaptive mechanisms that cancer cells employ to survive and even thrive in prolonged hypoxia, often lead to the emergence of drug resistance. Gaustad et al. have indicated that, following surgical excision of the tumor, chemo- or radiotherapy alone may not be sufficient considering that even diminutive tumors display the presence of hypoxic regions stemming from disrupted vascular function [126]. Moreover, if the radi- 
ation treatment is not continuous, it may lead to even faster repopulation of tumor cells. This phenomenon is caused by the re-oxygenation of hypoxic cells stemming from the decreased oxygen demand exhibited by dying cancer cells [127]. There are several possible mechanisms for chemo- and radiotherapy failure in the case of hypoxic tumor. Firstly, following HIF-dependent growth deceleration and inhibition of DNA replication, the DNA crosslinking or intercalating compounds have worse access to the tightly packed genetic material. Secondly, upon metabolic shift, which limits the activity of mitochondria, these organelles are less prone to mitochondrial DNA damage [101]. Furthermore, the lack of oxygen leads to the reduction in therapy-induced ROS (reactive oxygen species) levels, which are the mediators of irradiation-driven DNA damage [128]. Finally, hypoxia response elements are able to induce prosurvival pathways, mainly due to a loss of sensitivity to p53-mediated cell apoptosis by cancer cells [129].

For this reason, a plethora of novel therapeutic strategies targeting the hypoxic tumor microenvironment are being introduced to anti-melanoma treatment. They can be categorized into several groups of drugs, which target hypoxia indirectly (e.g., antiangiogenic molecules) or directly (e.g., inhibitors of HIF dimerization, nanoplatforms delivering oxygen) (Table 1$)$.

Table 1. A summary of Therapeutic Strategies Targeting the Hypoxic Melanoma Microenvironment.

\begin{tabular}{|c|c|c|}
\hline The Therapeutic Approach & Treatment Description & Results and Utilized Research Model \\
\hline \multirow{3}{*}{$\begin{array}{l}\text { Indirect targeting } \\
\text { (angiogenesis) }\end{array}$} & $\begin{array}{l}\text { Anti-VEGF antibodies } \\
\text { and multikinase inhibitors }\end{array}$ & $\begin{array}{l}\text { Phase I/II of clinical trials for novel drug } \\
\text { combinations are still ongoing. Monotherapies were } \\
\text { not effective, while combination treatment with } \\
\text { chemotherapy induced short-term response [130]. }\end{array}$ \\
\hline & sVEGFR (vector or induced by GM-CSF) & $\begin{array}{c}\text { Reduction of tumor angiogenesis, growth, and } \\
\text { metastasis was observed in vitro and using murine } \\
\text { melanoma model }[131,132] \text {. }\end{array}$ \\
\hline & $\begin{array}{l}\text { Promotion of endothelial gap junctions } \\
\qquad \text { (Sac-1004) }\end{array}$ & $\begin{array}{c}\text { In murine melanoma model, vasculature } \\
\text { normalization, inhibition of metastasis and EMT, } \\
\text { reduction of cancer stem-like cells population was } \\
\text { noted [133]. }\end{array}$ \\
\hline \multirow{4}{*}{$\begin{array}{l}\text { Direct targeting } \\
\text { (HIF- } 1 \alpha \text { inhibitors) }\end{array}$} & Acriflavine & $\begin{array}{l}\text { Inhibitors blocked the metabolism and proliferation } \\
\text { of melanoma cells in vitro [134]. }\end{array}$ \\
\hline & 2-methoxyestradiol & $\begin{array}{l}\text { Drug resensitized radioresistant cells and partially } \\
\text { suppressed their glycolytic state [135]. }\end{array}$ \\
\hline & Cinnamaldehyde & $\begin{array}{l}\text { Treatment reduced the invasiveness of melanoma } \\
\text { cells in vitro and in vivo [136]. }\end{array}$ \\
\hline & Arylsulfonamide (64B) & $\begin{array}{l}\text { The compound decreased the growth and metastasis } \\
\text { of murine uveal melanoma [8]. }\end{array}$ \\
\hline \multirow{3}{*}{$\begin{array}{l}\text { Direct targeting } \\
\text { (alleviation of } \\
\text { hypoxic conditions) }\end{array}$} & $\begin{array}{l}\text { Metformin (inhibition of oxygen } \\
\text { consumption) }\end{array}$ & $\begin{array}{l}\text { Improvement of anti-PD-L1 therapy was observed in } \\
\text { murine melanoma model [137]. }\end{array}$ \\
\hline & $\begin{array}{l}\text { Liposomes with hemoglobin and } \\
\text { doxorubicin, followed by radiotherapy }\end{array}$ & $\begin{array}{l}\text { Treatment efficiently blocked migration in vitro and } \\
\text { inhibited tumor growth in mice [138]. }\end{array}$ \\
\hline & $\begin{array}{l}\text { Multimodal platforms (CAT@aPDL1-SSL, } \\
\text { mZDC, Au@MTM-HA) }\end{array}$ & $\begin{array}{l}\text { Treated mice exhibited improved tumor infiltration } \\
\text { by cytotoxic T cells, prolonged survival, and reduced } \\
\text { metastasis rate [139-141]. }\end{array}$ \\
\hline \multirow{2}{*}{$\begin{array}{c}\text { Direct targeting } \\
\text { (oxygen-sensitive treatment) }\end{array}$} & $\begin{array}{l}\text { Prodrugs activated in hypoxia } \\
\quad \text { (tirapazamine, } \mathrm{TH}-302 \text { ) }\end{array}$ & $\begin{array}{l}\text { Combination therapy resulted in effective tumor size } \\
\text { reduction in mice }[142,143] \text {. }\end{array}$ \\
\hline & $\begin{array}{l}\text { Bacteria as drug delivery vectors } \\
\quad \text { (S. typhimurium) or } \\
\text { oncolytic inducers (C. novyi-NT) }\end{array}$ & $\begin{array}{l}\text { Bacteria-delivered vector reduced the proliferation } \\
\text { of melanoma cells, while the oncolytic strain } \\
\text { efficiently targeted solid tumors }[144,145] .\end{array}$ \\
\hline
\end{tabular}

VEGF, vascular endothelial growth factor; sVEGFR, soluble vascular endothelial growth factor receptor; GM-CSF, granulocyte-macrophage colony-stimulating factor; EMT, epithelial-to-mesenchymal transition; HIF-1 $\alpha$, hypoxia-inducible factor $1 \alpha$; PD-L1, programmed cell death ligand 1. 
Taking into account the importance of angiogenesis in tumor development, a great number of therapeutic strategies targeting proangiogenic pathways in anti-melanoma treatment were introduced, including anti-VEGF monoclonal antibodies (e.g., bevacizumab) or multikinase inhibitors (Table 1) [130]. Another approach to block VEGF is using a soluble form of VEGF receptor (sVEGFR), which neutralizes this growth factor. It was proposed as an adjuvant therapy allowing for vascular normalization using a sVEGFR vector under a hypoxia-inducible promotor [131]. Furthermore, GM-CSF (granulocyte-macrophage colony-stimulating factor), a cytokine secreted by fibroblasts, immune and endothelial cells, was able to shift macrophage production of VEGF towards SVEGFR1 in hypoxic conditions, which resulted in reduction of tumor mass (Table 1). These findings also suggest the use of GM-CSF intratumorally to limit melanoma growth [132]. However, it was shown that even in combination with chemotherapy these drugs were not able to significantly reduce tumor growth and metastasis in the long term [130]. Yura et al. observed that the inhibition of endothelial cell-dependent vascularization may even accelerate cancer progression due to the hypoxia-induced process of vasculogenic mimicry [146].

However, novel ways to normalize the tumor vasculature, rather than abrogate it, may improve overall therapeutic effect. Agrawal et al. developed Sac-1004, a compound potentiating endothelial cell junctions mediated by VE-cadherin (vascular endothelial cadherin) via cAMP (cyclic adenosine monophosphate)/Rac/cortactin pathway (Table 1). It enhances cell-cell contact integrity and reduces vascular leakage. Sac-1004 monotherapy significantly inhibited tumor metastasis, EMT signature, as well as resulted in a substantial drop in the cancer stem-like cell subpopulation. As a combination therapy with a chemotherapeutic — cisplatin, this novel compound synergistically induced melanoma cell apoptosis [133].

Owing to their critical involvement as mediators of the hypoxic response, HIF proteins appear to be promising therapy targets. Indeed, acriflavine, an inhibitor of HIF dimerization, was shown to block melanoma metabolism and proliferation even in normoxic conditions in cells expressing HIF irrespective of microenvironment oxygenation (Table 1) [134]. Radioresistant melanoma cell line was resensitized following treatment with HIF-1 $\alpha$ inhibitor-2-methoxyestradiol (Table 1). Moreover, resistant cells characterized by high expression of GLUT1 and LDH-A underwent partial suppression of their glycolytic state upon drug administration [135].

Cinnamaldehyde, a dietary flavonoid, was shown to block HIF accumulation in a PI3K/AKT/mTOR-dependent way (Table 1). Melanoma cells treated with this compound displayed reduced expression of VEGF, its receptor, MMP2/9, and markers of EMT, as well as decreased rates of invasive abilities and angiogenic activity [136]. Another drug, arylsulfonamide (64B), impaired the interaction between HIF- $1 \alpha$ and its nuclear co-factors p300/CBP (CREB-binding protein), thus diminishing the p300 recruitment to the CXCR4 (C-X-C chemokine receptor type 4) and MET (hepatocyte growth factor receptor) gene promoters and subsequent expression of these genes (Table 1). Uveal melanoma tumors treated with 64B exhibited decreased growth and rate of metastasis [147].

Currently, more complex therapeutic strategies, e.g., incorporating several active compounds and targeting molecules, are being introduced into the anticancer treatment. Alleviation of hypoxic conditions through the inhibition of oxygen consumption by cancer cells using metformin, was shown to improve the efficiency of anti-PD-1 immunotherapy (Table 1) [137]. Jiang et al. proposed combination therapy consisting of co-encapsulated doxorubicine and hemoglobin to deliver oxygen and mitigate hypoxia, followed by radiotherapy. The treatment sufficiently blocked the in vitro migration of melanoma cell and inhibited tumor growth in a mouse model (Table 1) [148]. Multifunctional immunoliposome CAT@aPDL1-SSL delivers the oxygen generating enzyme-catalase to the hypoxic regions of the tumor and reduces the extracellular acidity (Table 1). The delivery is driven by interaction between modified aPDL1 on the immunoliposome and PD-1 on the surface of the cancer cells. Using murine melanoma model, Hei et al. have shown improved 
activation and tumor infiltration by CD8+ CTLs upon mice treatment, and their subsequent prolonged survival [139].

The biomimetic nanoplatforms (mZCD and Au@MTM-HA) developed by two research groups combine multiple functionalities (Table 1). They deliver oxygen-generating molecules and inhibitors of ROS-scavenging antioxidants or chemotherapeutics. Additionally, the platforms include surface modifications to improve drug targeting. Using murine melanoma model, the effectiveness of mZCD treatment in combination with anti-PD-1 immunotherapy, as well as monotherapy with Au@MTM-HA was confirmed [140,141].

A class of prodrugs activated in hypoxic conditions was also tested in the case of melanoma. While monotherapy with tirapazamine, a DNA-damaging compound, failed to elicit a significant anticancer response, promising results were obtained using combination therapy with NTP (non-thermal plasma), also called 'cold plasma' (Table 1). NTP alone strongly induced ROS production and subsequent apoptotic response, whereas together with tirapazamine it displayed even higher effectiveness, resulting in $90 \%$ reduction in tumor volume in a murine melanoma model [142]. Another hypoxia-activated prodrug with DNA-alkylating activity, TH-302, also reduced tumor volume in combination with a standard chemotherapeutic (temozolimide) or inhibitor of multiple receptor tyrosine kinases (sunitinib), especially, when melanoma cells were first pre-treated with hypoxiatargeting drug (Table 1) [143,149].

An interesting approach to hypoxia-targeted drugs involves utilizing bacteria as drug delivery vectors. Liu et al. constructed a hypoxia-inducible vector expressing SPRY1/2 (sprouty RTK signaling antagonist 1/2), a negative regulator of receptor tyrosine kinase signaling, which was delivered to melanoma cells using an attenuated strain of Salmonella typhimurium (Table 1). They observed significant reduction in cancer cell proliferation mediated by inhibition of ERK phosphorylation [144]. A highly oxygen sensitive strain of the anaerobic bacterium Clostridium novyi-NT was also tested in hypoxic solid tumors including melanoma (Table 1). This strategy specifically targets the hypoxic and necrotic areas of tumors, induces oncolysis and immune response, and thus may be able to overcome the limitations of conventional anticancer therapy [145].

\section{Acidification}

\subsection{Molecular Basis of Tumor Microenvironment Acidification}

Another physicochemical factor that significantly affects the functioning of melanoma cells is tumor niche acidification. Although cancer cells produce excessive amounts of acidic molecules, the intracellular $\mathrm{pH}$ remains neutral or even basic [150]. This state is obtained through the activity of transporters and channels related to $\mathrm{pH}$ regulation, which export acid molecules outside [151]. However, buffer capacity of the tumor microenvironment reaches its limits and the $\mathrm{pH}$ of the tumor microenvironment becomes acidic. For instance, the extracellular $\mathrm{pH}(\mathrm{pHe})$ in the vicinity of normal differentiated cells is around 7.4, while the $\mathrm{pH}$ in the TME ranges between $\mathrm{pH} 5.5$ and $7.4[151,152]$.

There are several reasons responsible for this phenomenon. Firstly, cancer cells undergo the metabolic shift related to an increased level of glycolysis, even in the presence of oxygen, which is called "aerobic glycolysis". The final product of glycolysis, pyruvate, is then reduced to lactate and exported to the extracellular space, thus leading to the TME acidification (Figure 2) [153,154].

Carbon dioxide $\left(\mathrm{CO}_{2}\right)$, produced via the pentose phosphate pathway (PPP), highly active in tumor cells, also contributes to the acidification of the tumor niche (Figure 2). PPP produces one molecule of $\mathrm{CO}_{2}$ per one molecule of glucose. $\mathrm{CO}_{2}$ can be then hydrated and converted to hydrogen protons $\left(\mathrm{H}^{+}\right)$and bicarbonate by carbonic anhydrases (CA). This family of enzymes in humans consists of 16 isoforms. For instance, CAII acts intracellularly, while CAIX and CAXII extracellularly. $\mathrm{H}^{+}$ions produced by CAs then function as acids [155]. 


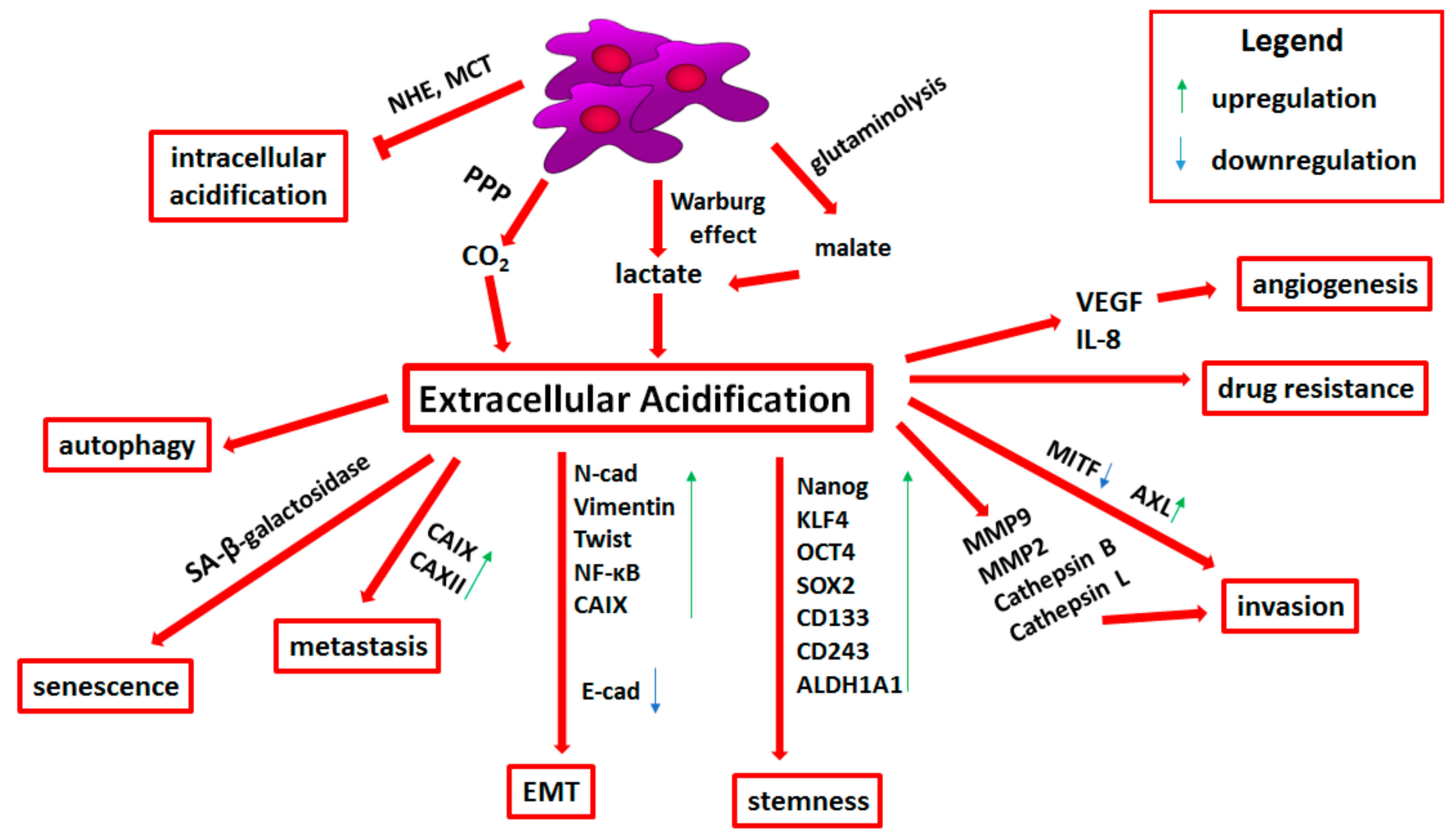

Figure 2. Influence of extracellular acidification on melanoma progression. Detailed descriptions can be found in the text. Abbreviations: NHE, Na/H exchanger; MCT, monocarboxylate transporters; PPP, pentose phosphate pathway; CA, carbonic anhydrase; N-cad, N-cadherin; NF-кB, nuclear factor-kappa B; E-cad, E-cadherin; KLF4, Krüppel-like factor 4; OCT4, octamer-binding transcription factor 4; SOX2, SRY-box transcription factor 2; ALDH, aldehyde dehydrogenase; MMP, matrix metalloproteinase; MITF, microphthalmia-associated transcription factor; VEGF, vascular endothelial growth factor; IL-8, interleukin 8; EMT, epithelial-to-mesenchymal transition.

Glutaminolysis is another catabolic process enhancing extracellular acidification (Figure 2). It involves the metabolic reactions of the tricarboxylic acid cycle and the malate-aspartate shuttle. Glutamine is converted to glutamate and then used to produce $\alpha$-ketoglutarate. $\alpha$-KG completes the TCA cycle in the mitochondria and undergoes conversion to malate. Following its export to the cytosol, malate is then decarboxylated to pyruvate and reduced to lactate, which, as mentioned above, contributes to the acidification of the tumor microenvironment $[151,156]$. The enzyme essential for lactic fermentation is lactate dehydrogenase (LDH). Its high level is correlated with the poor prognosis of advanced melanoma patients. This enzyme also constitutes a negative predictor of response to anticancer therapy [157].

Finally, acid uptake by skin fibroblasts has been shown to participate in maintaining the $\mathrm{pH}$ of the TME in a range favorable to tumor growth. The $\mathrm{H}^{+}$ions extruded by cancer cells can be taken up by surrounding fibroblasts and directly transported between them through connexin-43-containing gap junctions. This phenomenon, known as "acid venting" prevents excessive extracellular acidification in solid tumors. Acid uptake by dermal fibroblasts is stimulated by TGF $\beta 1$ [158]. Moreover, Shu et al. have shown that melanomaderived exosomes contain miR-155 and miR-210, which influence human adult dermal fibroblasts and lead to their metabolic reprogramming manifested by an increase in aerobic glycolysis, reduction of OXPHOS, and thus higher extracellular acidification [159].

Another miR affecting melanoma glycolysis is miR-216a-5p, which inhibits hexokinase 2 (HK2) - an enzyme initiating glycolysis. Reduction in HK2 activity results in a decrease of lactate level and acceleration of mitochondrial oxidation. Ectopic overexpression of miR$216-5 p$ in melanoma cells led to a decreased cell proliferation rate. Moreover, a negative 
correlation between expression of miR-216a-5p and HK2 level in patients was observed, while low miR-216-5p level was associated with worse prognosis [160]

Yang et al. demonstrated the impact of miR-489-3p on melanoma proliferation, migration, and invasion. MiR-489-3p inhibits SIX1 (sine oculis homeobox 1), which is a main transcription factor modulating aerobic glycolysis. In melanoma patients' samples, miR-489-3p level negatively correlated with SIX1 production, while its overexpression led to decreased proliferation, migration, invasion, and lactate production in vitro and reduced tumor volume in vivo [161]. Similar effect on extracellular acidification in melanoma has miR-150-5p, which similarly to miR-489-3p, inhibits SIX1, and thus reduces aerobic glycolysis. In patient-derived samples exhibiting elevated glycolysis, the expression of these miRs was diminished [162].

\subsection{Transporters Related to $\mathrm{pH}$ Regulation}

To avoid intracellular acidification, cells increase the expression or activity of transporters and $\mathrm{pH}$-regulating channels [151]. The protons produced inside the cells are removed from the cytosol by transport proteins such as the $\mathrm{Na} / \mathrm{H}$ exchanger (NHE), intensifying the acidification of the tumor niche (Figure 2) [152]. Vahle et al. indicated that NHE1 is strongly involved in the maintenance of intracellular $\mathrm{pH}$ homeostasis in melanoma [163]. Moreover, mutated BRAF-induced ERK stimulation intensifies phosphorylation and activation of NHE1. BRAF-mutated melanoma cells demonstrated increased intracellular $\mathrm{pH}$ dependent on elevated NHE1 activity [164]. In comparison with wild type BRAF, BRAF-mutated cells showed raised extracellular lactate concentrations [165]. On the other hand, Wahl et al. showed that lactate is extruded not by NHE, but mainly by monocarboxylate transporters MCT1 and MCT4, which transport lactate together with $\mathrm{H}^{+}$ion in the same direction. Culturing melanoma cells under acidic conditions $(\mathrm{pH}$ 6.7) increased the activity of MCT1, confirming their role in extracellular pH regulation (Figure 2) [166].

Research has shown that acidification within the tumor microenvironment may be associated with a more aggressive melanoma phenotype [167]. It was indicated that under the influence of acidic $\mathrm{pHe}$ melanoma cells showed increased secretion of proteinases and proangiogenic factors as well as elevated invasive abilities and more effective suppression of the immune system [168-170]. Moreover, when they were inoculated into mice, these melanoma cells exhibited increased potential to form pulmonary metastases [169]. Pinheiro et al. also demonstrated that MCT4 and GLUT1 expression was significantly upregulated in metastatic samples of melanoma and correlated with poor patients' prognosis. Furthermore, expression of MCT1 and MCT4 was associated with shorter overall survival [171].

The previously described phenomena of hypoxia and acidification are closely related. HIF molecule contributes to the Warburg effect, increasing the activity of LDH-A, which converts pyruvate to lactic acid, thus acidifying the TME [172]. Moreover, it has been shown that both oxygen deficiency and extracellular acidification induce the expression of genes encoding CAIX and CAXII [173,174]. Expression of these enzymes is associated with higher risk of metastasis and worse overall survival among melanoma patients (Figure 2) [175,176]. Andreucci et al. demonstrated that CAIX inhibitor-FC16-670A prevents upregulation of this metalloenzyme expression under acidosis, promoting apoptosis and necrosis only in acidified cancer cells [177]. Targeting CAIX seems to affect mainly acidic tumor cells exhibiting a highly malignant phenotype and high resistance to apoptosis. This form of treatment could represent a possible therapeutic approach to reduce tumor relapse [177]. Giuntini et al. indicated that CAXII inhibitor is also able to reduce invasive abilities of melanoma cells, which was associated with reduced phosphorylation of FAK kinase and the activity of MMP9 [176].

\subsection{Acid-Resistant Phenotype of Melanoma Cells}

In the case of melanoma, adaptation of cells to low $\mathrm{pH}$ and selection of cells showing an acid-resistant phenotype was observed. During this process, a significant part of the cells 
dies, however, acid-resistant cells also appear and after re-acclimatization to physiological $\mathrm{pH}$, show even greater invasive abilities. These cells also exhibit the upregulation of signaling pathways important for tissue remodeling, cell cycle control, and proliferation [178]. It was also indicated that acid-resistant cells, which then migrated to regions of physiological $\mathrm{pH}$, may more likely form metastasis [151]. Moreover, melanoma cells cultured in vitro under acidic conditions exhibit a remodeled phospholipids patterns. These cells produce longer and more unsaturated acyl chains compared to their counterparts cultured in neutral $\mathrm{pH}$. This process was mediated by upregulation of genes involved in acyl chain desaturation, elongation, and transfer to phospholipids. Changes in lipid composition are able to influence the membrane dynamics and activity of proteins regulating the $\mathrm{pH}$ balance between the intracellular and extracellular environments [53].

Another adaptation mechanism to the acidic environment relies on autophagy (Figure 2). Marino et al. showed that human melanoma cells grown under acidic conditions induce autophagy and reduce the absorption of nutrients such as glucose and leucine. Moreover, inhibition of autophagy through the ATG5 (autophagy related 5) knockdown reduced melanoma cell survival in low $\mathrm{pH}$ conditions $[151,179]$. Prolonged autophagy induced by nutrients deprivation, together with hypoxic conditions, may eventually lead to cell death. Matsuo et al. showed the importance of tumor microenvironment acidification mediated by lactic acid in promoting the survival of B16F10 mouse melanoma cells subjected to stress conditions [180].

\subsection{Epithelial-to-Mesenchymal Transition and Stemness in Acid-Adapted Melanoma Cells}

Exposure to acidic conditions is also able to promote epithelial-to-mesenchymal transition in melanoma cells. The acidic $\mathrm{pH}$ leads to a significant increase in the expression of EMT-related mesenchymal proteins such as N-cadherin, vimentin, and transcription factors-Twist and NF-kB, as well as results in E-cadherin downregulation (Figure 2) [181]. Moreover, it was demonstrated that acid-adapted melanoma cells co-express CD133, a known stemness marker, and CAIX to a greater extent compared to control cells. The latter one is a critical mediator of the self-renewal and invasive potential of cancer cells via transcriptional regulation of genes associated with EMT and stemness [182]. Melanoma cells cultured long-term in an acidic environment also demonstrated the induction of self-renewal and pluripotency markers (e.g., Nanog, KLF4 (Krüppel-like factor 4), OCT4 (octamer-binding transcription factor 4), and SOX2) as well as the overexpression of the cancer stem cells markers (e.g., CD133, CD243, and ALDH1A1) (Figure 2). This stem-like phenotype was reversible - when cells were retransferred to standard $\mathrm{pH}$, their self-renewal capacity and expression of stem-related markers was decreased [182].

\subsection{Extracellular Acidification-Induced Adhesion, Invasion, and Angiogenesis}

Acidity of the TME also affects the adhesion, migration, and invasion of cancer cells. In melanoma, several molecules such as integrins $\alpha_{2} \beta_{1}, \alpha_{5} \beta_{1}$, or $\alpha_{V} \beta_{3}$ are pHdependent $[183,184]$. Stock et al. demonstrated that extracellular $\mathrm{pH}$ affects the migration of human melanoma cells by modulating the interplay between cells and ECM. Migration is inhibited, when the interaction is too strong in acidic or too weak in alkaline pHe [185].

It was also shown that the melanoma cells migration depends on the activity of $\mathrm{NHE}$, which is strongly involved in the extracellular $\mathrm{pH}$ regulation. Its inhibition impaired melanoma cell motility [185]. Acidosis may promote the stability of focal adhesions through the stimulation of integrin-collagen binding in migratory membrane protrusions localized on the leading edge of the cell, so called lamellipodia [186]. NHE1 activity and low cell surface $\mathrm{pH}$ strengthen the cell-matrix interaction of melanoma cells at focal adhesions by modulating $\alpha_{2} \beta_{1}$ integrin conformation [187]. At the same time, increased NHE1 activity may impair adhesion between cancer cells, thereby facilitating their dissemination [188].

NHE is not evenly expressed on the surface of human melanoma cells. It mainly localizes on the leading edge of the lamellipodium structure. As a result, the front surface of the cell membrane has acidic $\mathrm{pH}$, while the back of the cell is more alkaline. This $\mathrm{pH}$ 
polarization can facilitate adhesion to the matrix at the front and the breakdown of focal adhesions at the rear of the cell $[188,189]$. Vahle et al. also indicated that in the presence of the NHE1-specific inhibitor cariporide, invasion was reduced by approximately 50\%, while adhesion was unaffected [163].

Intravenous microscopic analysis has shown that in vivo the tumor $\mathrm{pHe}$ is acidic and the regions with the lowest $\mathrm{pH}$ are associated with the highest invasive potential [190]. Extracellular acidosis also activates phospholipase D, ERK1/2, p38 MAPK, and NF- $\mathrm{B}$ in metastatic mouse melanoma, which induces MMP9 expression in cancer cells [191]. Rofstad et al. showed that human melanoma cells grown in vitro at acidic $\mathrm{pH}$ secrete increased amounts of a number of proteases (e.g., MMP2, MMP9, cathepsin B, and cathep$\sin$ L) as well as proangiogenic factors (i.e., VEGFA and IL-8) (Figure 2) [169]. It was also demonstrated that lactate secreted into the melanoma microenvironment is taken up by endothelial cells via MCT1, where it induces HIF-1 $\alpha$, and thus leads to the upregulation of growth factors associated with angiogenesis including VEGFR2 and bFGF (basic fibroblast growth factor) [192].

\subsection{Drug Resistance Related to Tumor Niche Acidification}

The acidic microenvironment can significantly affect the effectiveness of anticancer therapies, for instance, by influencing the distribution and absorption of slightly alkaline chemotherapeutic drugs, which leads to therapy resistance (Figure 2). This resistance is based on the "ion trap" model, taking into account the fact that weakly basic chemotherapeutic drugs accumulate in more acidic compartments. The acidic pHe can effectively impede weakly basic drugs from reaching their intracellular target, thereby reducing their cytotoxicity $[151,193]$. Moreover, following acidic exposure of melanoma cells, their increased resistance to anoikis was observed [24,25]. It was also indicated that BRAF V600E-mutated melanoma cells exposed to acidosis exhibited vemurafenib resistance, even though phosphorylated ERK was suppressed. In contrast, these cells were more sensitive to mTOR pathway inhibition than control cells, which suggests that acidification-induced melanoma phenotype exhibits preference towards mTOR rather than ERK signaling [194].

The TME acidosis also induces a senescent-like phenotype in melanoma cells characterized by induction of senescence-associated $\beta$-galactosidase activity, enlarged cell body size, cellular multinucleation, $\mathrm{G}_{1} / \mathrm{G}_{0}$ cell cycle arrest as well as inhibited cell proliferation (Figure 2). Transfer of acidosis-treated melanoma cells to physiological $\mathrm{pH}$ resulted in restoration of proliferation ability, even to a greater extent compared to previous conditions. Acidosis also led to enhanced resistance of melanoma cells to etoposide, a compound targeting actively dividing cells. This type of agent is not able to affect the acidosis-induced slow-proliferating cells, which results in drug resistance and may be responsible for tumor recurrence [167].

Moreover, in melanoma cell lines, extracellular acidosis induces upregulation of AXL receptor tyrosine kinase and reduction in MITF expression, which leads to the appearance of MITF ${ }^{\text {low }} / \mathrm{AXL}^{\text {high }}$ phenotype (Figure 2). Low MITF level is associated with invasive and senescent-like phenotype, which exhibits resistance to MAPK pathway inhibitors [167]. Recently, it was shown that melanoma cells use senescence to generate tumor-initiating cells with stem cell-like properties and to acquire chemotherapy resistance $[167,195]$.

\subsection{Immune Escape Mediated by Tumor Niche Acidification}

Extracellular lactic acid is also able to influence the activity of immune cells. It can inhibit the antitumor effects of cytotoxic T cells and NK cells as well as reduce lymphocyte proliferation and maturation of dendritic cells. These immunosuppressive effects are not due to acidity per se, but rather a result of the lactic acid influx through the lactate $/ \mathrm{H}^{+}$ co-transporter, which under neutral $\mathrm{pH}$ removes lactic acid from leukocytes [168,196,197]. It was demonstrated that high levels of melanoma cells-derived lactic acid present in the TME blocks the export of this molecule from T cells, thus disrupting their metabolism and function [198]. It also inhibits IFN $\gamma$ production by CTLs [199]. 
Bohn et al. showed that intratumoral acidosis triggers cAMP-dependent signal transduction leading to the expression of the transcriptional repressor ICER (inducible cAMP early repressor) in tumor-associated macrophages, which induces their functional polarization toward a non-inflammatory M2 phenotype and promotes tumor growth [200].

Combination of bicarbonate, which neutralizes tumor acidity, with routinely used in melanoma anti-CTLA4 or anti-PD-1 therapy significantly improved the antitumor effects of these drugs in the murine melanoma model, which was resistant to bicarbonate monotherapy. Authors postulated that therapy based on bicarbonate acts by buffering the tumor $\mathrm{pH}$ to more neutral values, without affecting systemic $\mathrm{pH}$ [201]. This strategy was also used to improve cytotoxic $\mathrm{T}$ cell activity in patients with relapsed acute myeloid leukemia after allogeneic hematopoietic cell transplantation. Here, it was shown that sodium bicarbonate was responsible for $\mathrm{T}$ cell metabolic rescue, allowing for the incorporation of lactic acid in the TCA cycle as an additional energy source and thus increased IFN $\gamma$ production [202].

Pilon-Thomas et al. also suggested that a similar effect could be achieved with the application of either isoform-specific CAIX or LDH inhibitors [201]. Chafe et al. confirmed this hypothesis. Expression of CAIX was associated with reduced immune system anticancer response of malignant melanoma patients. They also demonstrated that application of CAIX inhibitor combined with immune-checkpoint inhibitors led to the sensitization of melanoma to immune therapy. It was related to enhanced T helper cell response occurring as a result of the reduction of PD-1 expression on T cells present within the tumor niche [175].

\subsection{Therapies Targeting Extracellular Acidification}

There are some concepts of therapies directed against the acidity of the TME. One approach involves the development of weakly acidic compounds, which are able to enter the interior of solid tumors and release toxins in an acidic microenvironment [203]. Another therapeutic strategy is based on the inhibition of cellular proton pumps, which reduce the intracellular $\mathrm{pH}$. This lowered $\mathrm{pH}$ within cells leads to decreased proliferation rate and induction of apoptosis in cancer cells. Milito et al. demonstrated that the proton pump inhibitor esomeprazole, activated by acidity, neutralizes tumor $\mathrm{pH}$ via inhibition of proton ejection. It led to the reduction of melanoma cells proliferation in vitro and promoted their apoptosis through caspase activation. Moreover, esomeprazole diminished melanoma tumor growth in mice and significantly increased the survival of examined animals, without any relevant side effects [204]. Administration of another proton pump inhibitor, omeprazole, significantly enhanced the effect of cisplatin in melanoma cells in mice, possibly due to the fact that cisplatin is a slightly alkaline drug, whose intracellular uptake is reduced in acidic TME [205].

\section{Conclusions}

The melanoma microenvironment is a very intricate structure, which influences the tumor progression and drug resistance. It consists of various stromal cells, i.e., keratinocytes, cancer-associated fibroblasts, adipocytes, and immune cells, connected through elements of extracellular matrix. The physicochemical aspects of the tumor niche such as acidity and oxygenation are also important for melanoma growth. Accurate and thorough knowledge concerning the vicinity of tumors, including melanoma, is critical to understand molecular basis of cancer progression and further develop novel therapeutic strategies. For maximum efficiency, the treatment has to focus not only on the elimination of cancer cells, but also has to consider the crosstalk between malignant cells and its niche. The data on the role of the features of tumor microenvironment such as hypoxia or extracellular acidification are very valuable, as they allow for better insight into the biology of melanoma cells. Processes like metabolism reprogramming, angiogenesis, stemness and cell plasticity, invasiveness, immune escape, and drug resistance are highly influenced by tumor niche oxygenation and acidification. Further development of hypoxia- and acidification-targeted therapies 
seems also valid, taking into account promising results obtained using in vitro and in vivo melanoma models.

Funding: This research was funded by the National Science Centre, Poland, with a grant received by Dorota Nowak (OPUS 15, No. 2018/29/B/NZ5/00967). Publication of this article was financially supported by the Excellence Initiative-Research University (IDUB) program for the University of Wroclaw.

Institutional Review Board Statement: Not applicable.

Informed Consent Statement: Not applicable.

Data Availability Statement: Data sharing not applicable.

Conflicts of Interest: The authors declare no conflict of interest. The funders had no role in the design of the study; in the collection, analyses, or interpretation of data; in the writing of the manuscript, or in the decision to publish the results.

\section{References}

1. Miller, A.J.; Mihm, M.C. Melanoma. N. Engl. J. Med. 2006, 355, 51-65. [CrossRef]

2. Costin, G.E.; Hearing, V.J. Human skin pigmentation: Melanocytes modulate skin color in response to stress. FASEB J. 2007, 21, 976-994. [CrossRef]

3. Grzywa, T.M.; Paskal, W.; Włodarski, P.K. Intratumor and Intertumor Heterogeneity in Melanoma. Transl. Oncol. 2017, 10, 956-975. [CrossRef]

4. $\quad$ Ekedahl, H.; Cirenajwis, H.; Harbst, K.; Carneiro, A.; Nielsen, K.; Olsson, H.; Lundgren, L.; Ingvar, C.; Jönsson, G. The clinical significance of $B R A F$ and NRAS mutations in a clinic-based metastatic melanoma cohort. Br. J. Dermatol. 2013, 169, $1049-1055$. [CrossRef]

5. Garbe, C.; Amaral, T.; Peris, K.; Hauschild, A.; Arenberger, P.; Bastholt, L.; Bataille, V.; del Marmol, V.; Dréno, B.; Fargnoli, M.C.; et al. European consensus-based interdisciplinary guideline for melanoma. Part 2: Treatment-Update 2019. Eur. J. Cancer 2020, 126, 159-177. [CrossRef]

6. Rosell, R.; Karachaliou, N.; Morales-Espinosa, D.; Costa, C.; Molina, M.A.; Sansano, I.; Gasco, A.; Viteri, S.; Massuti, B.; Wei, J.; et al. Adaptive resistance to targeted therapies in cancer. Transl. Lung Cancer Res. 2013, 2, 152-159. [CrossRef] [PubMed]

7. Mazurkiewicz, J.; Simiczyjew, A.; Dratkiewicz, E.; Ziętek, M.; Matkowski, R.; Nowak, D. Stromal Cells Present in the Melanoma Niche Affect Tumor Invasiveness and Its Resistance to Therapy. Int. J. Mol. Sci. 2021, 22, 529. [CrossRef]

8. Ruiter, D.; Bogenrieder, T.; Elder, D.; Herlyn, M. Melanoma-Stroma interactions: Structural and functional aspects. Lancet Oncol. 2002, 3, 35-43. [CrossRef]

9. Gurzu, S.; Beleaua, M.A.; Jung, I. The role of tumor microenvironment in development and progression of malignant melanomas-a systematic review. Rom. J. Morphol. Embryol. 2018, 59, 23-28. [PubMed]

10. Simiczyjew, A.; Dratkiewicz, E.; Mazurkiewicz, J.; Ziętek, M.; Matkowski, R.; Nowak, D. The Influence of Tumor Microenvironment on Immune Escape of Melanoma. Int. J. Mol. Sci. 2020, 21, 8359. [CrossRef] [PubMed]

11. Muz, B.; de la Puente, P.; Azab, F.; Azab, A.K. The role of hypoxia in cancer progression, angiogenesis, metastasis, and resistance to therapy. Hypoxia 2015, 3, 83. [CrossRef] [PubMed]

12. Semenza, G.L. Hypoxia, clonal selection, and the role of HIF-1 in tumor progression. Crit. Rev. Biochem. Mol. Biol. 2000, 35, 71-103. [CrossRef] [PubMed]

13. Pouysségur, J.; Dayan, F.; Mazure, N.M. Hypoxia signalling in cancer and approaches to enforce tumour regression. Nature 2006, 441, 437-443. [CrossRef]

14. Evans, S.M.; Schrlau, A.E.; Chalian, A.A.; Zhang, P.; Koch, C.J. Oxygen levels in normal and previously irradiated human skin as assessed by EF5 binding. J. Investig. Dermatol. 2006, 126, 2596-2606. [CrossRef] [PubMed]

15. Vaupel, P. Hypoxia and Aggressive Tumor Phenotype: Implications for Therapy and Prognosis. Oncologist 2008, 13, 21-26. [CrossRef]

16. Lartigau, E.; Randrianarivelo, H.; Avril, M.F.; Margulis, A.; Spatz, A.; Eschwège, F.; Guichard, M. Intratumoral oxygen tension in metastatic melanoma. Melanoma Res. 1997, 7, 400-406. [CrossRef] [PubMed]

17. Huang, Y.; Lin, D.; Taniguchi, C.M. Hypoxia inducible factor (HIF) in the tumor microenvironment: Friend or foe? Sci. China Life Sci. 2017, 60, 1114-1124. [CrossRef]

18. Mole, D.R.; Blancher, C.; Copley, R.R.; Pollard, P.J.; Gleadle, J.M.; Ragousis, J.; Ratcliffe, P.J. Genome-wide association of hypoxiainducible factor (HIF)- $1 \alpha$ and HIF- $2 \alpha$ DNA binding with expression profiling of hypoxia-inducible transcripts. J. Biol. Chem. 2009, 284, 16767-16775. [CrossRef]

19. Wang, G.L.; Jiang, B.H.; Rue, E.A.; Semenza, G.L. Hypoxia-inducible factor 1 is a basic-helix-loop-helix-PAS heterodimer regulated by cellular O2 tension. Proc. Natl. Acad. Sci. USA 1995, 92, 5510-5514. [CrossRef]

20. Weidemann, A.; Johnson, R.S. Biology of HIF-1 $\alpha$. Cell Death Differ. 2008, 15, 621-627. [CrossRef] 
21. Semenza, G.L. Oxygen sensing, hypoxia-inducible factors, and disease pathophysiology. Annu. Rev. Pathol. Mech. Dis. 2014, 9, 47-71. [CrossRef] [PubMed]

22. Masoud, G.N.; Li, W. HIF-1 $\alpha$ pathway: Role, regulation and intervention for cancer therapy. Acta Pharm. Sin. B 2015, 5, 378-389. [CrossRef] [PubMed]

23. D'Ignazio, L.; Batie, M.; Rocha, S. Hypoxia and inflammation in cancer, focus on HIF and NF-kB. Biomedicines 2017, 5, 21. [CrossRef] [PubMed]

24. Luo, W.; Wang, Y. Epigenetic regulators: Multifunctional proteins modulating hypoxia-inducible factor- $\alpha$ protein stability and activity. Cell. Mol. Life Sci. 2018, 75, 1043-1056. [CrossRef]

25. Zhong, H.; De Marzo, A.M.; Laughner, E.; Lim, M.; Hilton, D.A.; Zagzag, D.; Buechler, P.; Isaacs, W.B.; Semenza, G.L.; Jonathan, W. Simons Overexpression of Hypoxia-inducible Factor $1 \alpha$ in Common Human Cancers and Their Metastases. Cancer Res. 1999, $59,5830-5835$.

26. Mouriaux, F.; Sanschagrin, F.; Diorio, C.; Landreville, S.; Comoz, F.; Petit, E.; Bernaudin, M.; Rousseau, A.P.; Bergeron, D.; Morcos, M. Increased HIF-1 $\alpha$ expression correlates with cell proliferation and vascular markers CD31 and VEGF-A in uveal melanoma. Investig. Ophthalmol. Vis. Sci. 2014, 55, 1277-1283. [CrossRef] [PubMed]

27. Mills, C.N.; Joshi, S.S.; Niles, R.M. Expression and function of hypoxia inducible factor-1 alpha in human melanoma under non-hypoxic conditions. Mol. Cancer 2009, 8, 104. [CrossRef]

28. Kuphal, S.; Winklmeier, A.; Warnecke, C.; Bosserhoff, A.K. Constitutive HIF-1 activity in malignant melanoma. Eur. J. Cancer 2010, 46, 1159-1169. [CrossRef]

29. Ercin, M.E.; Bozdoğan, Ö.; Çavuşoğlu, T.; Bozdoğan, N.; Atasoy, P.; Koçak, M. Hypoxic gene signature of primary and metastatic melanoma cell lines: Focusing on HIF-1 $\beta$ and NDRG-1. Balkan Med. J. 2020, 37, 15-23. [CrossRef]

30. Hao, T.; Li, C.X.; Ding, X.Y.; Xing, X.J. MicroRNA-363-3p/p21(Cip1/Waf1) axis is regulated by HIF-2 $\alpha$ in mediating stemness of melanoma cells. Neoplasma 2019, 66, 427-436. [CrossRef]

31. Giatromanolaki, A.; Sivridis, E.; Kouskoukis, C.; Gatter, K.C.; Harris, A.L.; Koukourakis, M.I. Hypoxia-inducible factors 1AE and $2 \mathrm{AE}$ are related to vascular endothelial growth factor expression and a poorer prognosis in nodular malignant melanomas of the skin. Melanoma Res. 2003, 13, 493-501. [CrossRef] [PubMed]

32. Steunou, A.L.; Ducoux-Petit, M.; Lazar, I.; Monsarrat, B.; Erard, M.; Muller, C.; Clottes, E.; Burlet-Schiltz, O.; Nieto, L. Identification of the hypoxia-inducible factor $2 \alpha$ nuclear interactome in melanoma cells reveals master proteins involved in melanoma development. Mol. Cell. Proteom. 2013, 12, 736-748. [CrossRef] [PubMed]

33. Hoefflin, R.; Harlander, S.; Schäfer, S.; Metzger, P.; Kuo, F.; Schönenberger, D.; Adlesic, M.; Peighambari, A.; Seidel, P.; Chen, C.Y.; et al. HIF- $1 \alpha$ and HIF- $2 \alpha$ differently regulate tumour development and inflammation of clear cell renal cell carcinoma in mice. Nat. Commun. 2020, 11, 4111. [CrossRef] [PubMed]

34. Liu, S.; Zhang, G.; Guo, J.; Chen, X.; Lei, J.; Ze, K.; Dong, L.; Dai, X.; Gao, Y.; Song, D.; et al. Loss of Phd2 cooperates with BRAF V600E to drive melanomagenesis. Nat. Commun. 2018, 9, 5426. [CrossRef] [PubMed]

35. Greijer, A.E.; Van Der Wall, E. The role of hypoxia inducible factor 1 (HIF-1) in hypoxia induced apoptosis. J. Clin. Pathol. 2004, 57, 1009-1014. [CrossRef] [PubMed]

36. Mazar, J.; Qi, F.; Lee, B.; Marchica, J.; Govindarajan, S.; Shelley, J.; Li, J.-L.; Ray, A.; Perera, R.J. MicroRNA 211 Functions as a Metabolic Switch in Human Melanoma Cells. Mol. Cell. Biol. 2016, 36, 1090-1108. [CrossRef]

37. Maadi, H.; Moshtaghian, A.; Taha, M.F.; Mowla, S.J.; Kazeroonian, A.; Haass, N.K.; Javeri, A. Multimodal tumor suppression by miR-302 cluster in melanoma and colon cancer. Int. J. Biochem. Cell Biol. 2016, 81, 121-132. [CrossRef]

38. Leszczynska, K.B.; Foskolou, I.P.; Abraham, A.G.; Anbalagan, S.; Tellier, C.; Haider, S.; Span, P.N.; O’Neill, E.E.; Buffa, F.M.; Hammond, E.M. Hypoxia-induced p53 modulates both apoptosis and radiosensitivity via AKT. J. Clin. Investig. 2015, 125, 2385-2398. [CrossRef]

39. Murphy, M.; Phelps, A.; Swede, H.; Claffey, K. Hypoxia-induced response of cell cycle and apoptosis regulators in melanoma. Int. J. Dermatol. 2012, 51, 1263-1267. [CrossRef]

40. Warren, C.F.A.; Wong-Brown, M.W.; Bowden, N.A. BCL-2 family isoforms in apoptosis and cancer. Cell Death Dis. 2019, 10, 177. [CrossRef]

41. Flamant, L.; Notte, A.; Ninane, N.; Raes, M.; Michiels, C. Anti-apoptotic role of HIF-1 and AP-1 in paclitaxel exposed breast cancer cells under hypoxia. Mol. Cancer 2010, 9, 191. [CrossRef]

42. Boisvert-Adamo, K.; Longmate, W.; Abel, E.V.; Aplin, A.E. Mcl-1 is required for melanoma cell resistance to anoikis. Mol. Cancer Res. 2009, 7, 549-556. [CrossRef]

43. Bacchi, P.S.; Bloise, A.C.; Bustos, S.O.; Zimmermann, L.; Chammas, R.; Rabbani, S.R. Metabolism under hypoxia in Tm1 murine melanoma cells is affected by the presence of galectin-3, a metabolomics approach. SpringerPlus 2014, 3, 470. [CrossRef]

44. Hayashi, Y.; Jia, W.; Kidoya, H.; Muramatsu, F.; Tsukada, Y.; Takakura, N. Galectin-3 Inhibits Cancer Metastasis by Negatively Regulating Integrin $\beta 3$ Expression. Am. J. Pathol. 2019, 189, 900-910. [CrossRef]

45. Bustos, S.O.; da Silva Pereira, G.J.; de Freitas Saito, R.; Gil, C.D.; Zanatta, D.B.; Smaili, S.S.; Chammas, R. Galectin-3 sensitized melanoma cell lines to vemurafenib (PLX4032) induced cell death through prevention of autophagy. Oncotarget 2018, 9, 14567-14579. [CrossRef]

46. Wang, W.; Wang, D.; Li, H. Initiation of premature senescence by Bcl-2 in hypoxic condition. Int. J. Clin. Exp. Pathol. 2014, 7, 2446-2453. [PubMed] 
47. Mo, J.; Sun, B.; Zhao, X.; Gu, Q.; Dong, X.; Liu, Z.; Ma, Y.; Zhao, N.; Tang, R.; Liu, Y.; et al. Hypoxia-induced senescence contributes to the regulation of microenvironment in melanomas. Pathol. Res. Pract. 2013, 209, 640-647. [CrossRef]

48. Shimizu, T.; Nagane, M.; Suzuki, M.; Yamauchi, A.; Kato, K.; Kawashima, N.; Nemoto, Y.; Maruo, T.; Kawakami, Y.; Yamashita, T. Tumor hypoxia regulates ganglioside GM3 synthase, which contributes to oxidative stress resistance in malignant melanoma. Biochim. Biophys. Acta Gen. Subj. 2020, 1864, 129723. [CrossRef] [PubMed]

49. Wang, X.Q.; Sun, P.; Go, L.; Koti, V.; Fliman, M.; Paller, A.S. Ganglioside GM3 promotes carcinoma cell proliferation via urokinase plasminogen activator-induced extracellular signal-regulated kinase-independent p70S6 kinase signaling. J. Investig. Dermatol. 2006, 126, 2687-2696. [CrossRef] [PubMed]

50. Daskalaki, I.; Gkikas, I.; Tavernarakis, N. Hypoxia and selective autophagy in cancer development and therapy. Front. Cell Dev. Biol. 2018, 6, 104. [CrossRef]

51. Buart, S.; Terry, S.; Noman, M.Z.; Lanoy, E.; Boutros, C.; Fogel, P.; Dessen, P.; Meurice, G.; Gaston-Mathé, Y.; Vielh, P.; et al. Transcriptional response to hypoxic stress in melanoma and prognostic potential of GBE1 and BNIP3. Oncotarget 2017, 8, 108786-108801. [CrossRef] [PubMed]

52. Giatromanolaki, A.N.; St Charitoudis, G.; Bechrakis, N.E.; Kozobolis, V.P.; Koukourakis, M.I.; Foerster, M.H.; Sivridis, E.L. Autophagy patterns and prognosis in uveal melanomas. Mod. Pathol. 2011, 24, 1036-1045. [CrossRef] [PubMed]

53. Matsuo, T.; Daishaku, S.; Sadzuka, Y. Lactic acid promotes cell survival by blocking autophagy of B16F10 mouse melanoma cells under glucose deprivation and hypoxic conditions. Biol. Pharm. Bull. 2019, 42, 837-839. [CrossRef]

54. Schito, L. Hypoxia-dependent angiogenesis and lymphangiogenesis in cancer. In Advances in Experimental Medicine and Biology; Springer: New York, NY, USA, 2019; Volume 1136, pp. 71-85.

55. De Palma, M.; Biziato, D.; Petrova, T.V. Microenvironmental regulation of tumour angiogenesis. Nat. Rev. Cancer 2017, 17, 457-474. [CrossRef]

56. Das, A.M.; Pescatori, M.; Vermeulen, C.E.; Rens, J.A.P.; Seynhaeve, A.L.B.; Koning, G.A.; Eggermont, A.M.M.; ten Hagen, T.L.M. Melanomas prevent endothelial cell death under restrictive culture conditions by signaling through AKT and p38 MAPK/ERK1/2 cascades. Oncoimmunology 2016, 5, e1219826. [CrossRef] [PubMed]

57. Klimkiewicz, K.; Weglarczyk, K.; Collet, G.; Paprocka, M.; Guichard, A.; Sarna, M.; Jozkowicz, A.; Dulak, J.; Sarna, T.; Grillon, C.; et al. A 3D model of tumour angiogenic microenvironment to monitor hypoxia effects on cell interactions and cancer stem cell selection. Cancer Lett. 2017, 396, 10-20. [CrossRef]

58. Spinella, F.; Caprara, V.; Cianfrocca, R.; Rosanò, L.; Di Castro, V.; Garrafa, E.; Natali, P.G.; Bagnato, A. The interplay between hypoxia, endothelial and melanoma cells regulates vascularization and cell motility through endothelin- 1 and vascular endothelial growth factor. Carcinogenesis 2014, 35, 840-848. [CrossRef]

59. Lee, S.; Goldfinger, L.E. RLIP76 regulates HIF-1 activity, VEGF expression and secretion in tumor cells, and secretome transactivation of endothelial cells. FASEB J. 2014, 28, 4158-4168. [CrossRef]

60. Yoon, N.A.; Jung, S.J.; Choi, S.H.; Ryu, J.H.; Mani, M.; Lee, U.H.; Vo, M.T.; Jeon, D.Y.; Chung, S.W.; Ju Lee, B.; et al. DRG2 supports the growth of primary tumors and metastases of melanoma by enhancing VEGF-A expression. FEBS J. 2020, 287, 2070-2086. [CrossRef]

61. Gabellini, C.; De Luca, T.; Trisciuoglio, D.; Desideri, M.; Di Martile, M.; Passeri, D.; Candiloro, A.; Biffoni, M.; Rizzo, M.G.; Orlandi, A.; et al. BH4 domain of bcl-2 protein is required for its proangiogenic function under hypoxic condition. Carcinogenesis 2013, 34, 2558-2567. [CrossRef]

62. Hu, K.; Babapoor-Farrokhran, S.; Rodrigues, M.; Deshpande, M.; Puchner, B.; Kashiwabuchi, F.; Hassan, S.J.; Asnaghi, L.; Handa, J.T.; Merbs, S.; et al. Hypoxia-inducible factor 1 upregulation of both VEGF and ANGPTL4 is required to promote the angiogenic phenotype in uveal melanoma. Oncotarget 2016, 7, 7816-7828. [CrossRef]

63. Xu, X.; Zong, Y.; Gao, Y.; Sun, X.; Zhao, H.; Luo, W.; Jia, S. VEGF Induce Vasculogenic Mimicry of Choroidal Melanoma through the PI3k Signal Pathway. Biomed Res. Int. 2019, 2019, 3909102. [CrossRef] [PubMed]

64. Ene Nicolae, C.D.; Nicolae, I. Interleukin 8 serum concentration, but not lactate dehydrogenase activity, positively correlates to CD34 antigen in melanoma tumors. J. Immunoass. Immunochem. 2016, 37, 463-471. [CrossRef] [PubMed]

65. Timani, K.A.; Gyorffy, B.; Liu, Y.; Mohammad, K.S.; He, J.J. Tip110/SART3 regulates IL-8 expression and predicts the clinical outcomes in melanoma. Mol. Cancer 2018, 17, 124. [CrossRef] [PubMed]

66. Wen, Y.; Li, J.; Koo, J.; Shin, S.S.; Lin, Y.; Jeong, B.S.; Mehnert, J.M.; Chen, S.; Cohen-Sola, K.A.; Goydos, J.S. Activation of the glutamate receptor GRM1 enhances angiogenic signaling to drive melanoma progression. Cancer Res. 2014, 74, $2499-2509$. [CrossRef] [PubMed]

67. Gascard, P.; Tlsty, T.D. Carcinoma-associated fibroblasts: Orchestrating the composition of malignancy. Genes Dev. 2016, 30, 1002-1019. [CrossRef] [PubMed]

68. Comito, G.; Giannoni, E.; Di Gennaro, P.; Segura, C.P.; Gerlini, G.; Chiarugi, P. Stromal fibroblasts synergize with hypoxic oxidative stress to enhance melanoma aggressiveness. Cancer Lett. 2012, 324, 31-41. [CrossRef]

69. Arozarena, I.; Wellbrock, C. Phenotype plasticity as enabler of melanoma progression and therapy resistance. Nat. Rev. Cancer 2019, 19, 377-391. [CrossRef]

70. Levy, C.; Khaled, M.; Fisher, D.E. MITF: Master regulator of melanocyte development and melanoma oncogene. Trends Mol. Med. 2006, 12, 406-414. [CrossRef] 
71. Laugier, F.; Delyon, J.; André, J.; Bensussan, A.; Dumaz, N. Hypoxia and MITF regulate KIT oncogenic properties in melanocytes. Oncogene 2016, 35, 2070-2077. [CrossRef]

72. Lenggenhager, D.; Curioni-Fontecedro, A.; Storz, M.; Shakhova, O.; Sommer, L.; Widmer, D.S.; Seifert, B.; Moch, H.; Dummer, R.; Mihic-Probst, D. An aggressive hypoxia related subpopulation of melanoma cells is TRP-2 negative. Transl. Oncol. 2014, 7, 206-212. [CrossRef]

73. Fernández-Barral, A.; Orgaz, J.L.; Gomez, V.; del Peso, L.; Calzada, M.J.; Jiménez, B. Hypoxia negatively regulates antimetastatic PEDF in melanoma cells by a hypoxia inducible factor-independent, autophagy dependent mechanism. PLoS ONE 2012, 7, e32989. [CrossRef]

74. Li, H.; Chen, J.; Wang, X.; He, M.; Zhang, Z.; Cen, Y. Nodal induced by hypoxia exposure contributes to dacarbazine resistance and the maintenance of stemness in melanoma cancer stem-like cells. Oncol. Rep. 2018, 39, 2855-2864. [CrossRef]

75. Li, W.; Zhou, Y. LRIG1 acts as a critical regulator of melanoma cell invasion, migration, and vasculogenic mimicry upon hypoxia by regulating EGFR/ERK-triggered epithelial-mesenchymal transition. Biosci. Rep. 2019, 39, BSR20181165. [CrossRef]

76. Asnaghi, L.; Lin, M.H.; Lim, K.S.; Lim, K.J.; Tripathy, A.; Wendeborn, M.; Merbs, S.L.; Handa, J.T.; Sodhi, A.; Bar, E.E.; et al. Hypoxia promotes uveal melanoma invasion through enhanced notch and MAPK activation. PLoS ONE 2014, 9, e105372. [CrossRef] [PubMed]

77. Aster, J.C.; Pear, W.S.; Blacklow, S.C. The Varied Roles of Notch in Cancer. Annu. Rev. Pathol. Mech. Dis. 2017, 12, 245-275. [CrossRef] [PubMed]

78. Liu, S.; Kumar, S.M.; Martin, J.S.; Yang, R.; Xu, X. Snail1 mediates hypoxia-induced melanoma progression. Am. J. Pathol. 2011, 179, 3020-3031. [CrossRef] [PubMed]

79. Richichi, B.; Comito, G.; Renaudet, O.; Fiore, M.; Marra, A.; Stecca, B.; Pasquato, L.; Chiarugi, P.; Nativi, C. Role of a Preorganized Scaffold Presenting Four Residues of a GM-3 Lactone Mimetic on Melanoma Progression. ACS Med. Chem. Lett. 2016, 7, 28-33. [CrossRef] [PubMed]

80. Bi, J.; Li, P.; Li, C.; He, J.; Wang, Y.; Zhang, H.; Fan, X.; Jia, R.; Ge, S. The SDF-1/CXCR4 chemokine axis in uveal melanoma cell proliferation and migration. Tumor Biol. 2016, 37, 4175-4182. [CrossRef]

81. Linnskog, R.; Jönsson, G.; Axelsson, L.; Prasad, C.P.; Andersson, T. Interleukin-6 drives melanoma cell motility through p38 $\alpha$-MAPK-dependent up-regulation of WNT5A expression. Mol. Oncol. 2014, 8, 1365-1378. [CrossRef]

82. Lawson, C.D.; Ridley, A.J. Rho GTPase signaling complexes in cell migration and invasion. J. Cell Biol. 2017, $217,447-457$. [CrossRef]

83. Tátrai, E.; Bartal, A.; Gacs, A.; Paku, S.; Kenessey, I.; Garay, T.; Hegedus, B.; Molnár, E.; Cserepes, M.T.; Hegedus, Z.; et al. Cell type-dependent HIF1 $\alpha$-mediated effects of hypoxia on proliferation, migration and metastatic potential of human tumor cells. Oncotarget 2017, 8, 44498-44510. [CrossRef]

84. Silva, P.; Mendoza, P.; Rivas, S.; Díaz, J.; Moraga, C.; Quest, A.F.G.; Torres, V.A. Hypoxia promotes Rab5 activation, leading to tumor cell migration, invasion and metastasis. Oncotarget 2016, 7, 29548-29562. [CrossRef] [PubMed]

85. Finger, E.C.; Castellini, L.; Rankin, E.B.; Vilalta, M.; Krieg, A.J.; Jiang, D.; Banh, A.; Zundel, W.; Powell, M.B.; Giaccia, A.J. Hypoxic induction of AKAP12 variant 2 shifts PKA-mediated protein phosphorylation to enhance migration and metastasis of melanoma cells. Proc. Natl. Acad. Sci. USA 2015, 112, 4441-4446. [CrossRef] [PubMed]

86. Xu, B.; Zhang, X.; Gao, Y.; Song, J.; Shi, B. Microglial Annexin A3 promoted the development of melanoma via activation of hypoxia-inducible factor- $1 \alpha /$ vascular endothelial growth factor signaling pathway. J. Clin. Lab. Anal. 2020, 35, e23622. [CrossRef] [PubMed]

87. Eble, J.A.; Niland, S. The extracellular matrix in tumor progression and metastasis. Clin. Exp. Metastasis 2019, 36, 171-198. [CrossRef] [PubMed]

88. Cowden Dahl, K.D.; Robertson, S.E.; Weaver, V.M.; Simon, M.C. Hypoxia-inducible factor regulates $\alpha \mathrm{v} \beta 3$ integrin cell surface expression. Mol. Biol. Cell 2005, 16, 1901-1912. [CrossRef]

89. Rezvani, H.R.; Ali, N.; Nissen, L.J.; Harfouche, G.; De Verneuil, H.; Taïeb, A.; Mazurier, F. HIF-1 $\alpha$ in epidermis: Oxygen sensing, cutaneous angiogenesis, cancer, and non-cancer disorders. J. Investig. Dermatol. 2011, 131, 1793-1805. [CrossRef]

90. Chung, H.; Suh, E.K.; Han, I.O.; Oh, E.S. Keratinocyte-derived laminin-332 promotes adhesion and migration in melanocytes and melanoma. J. Biol. Chem. 2011, 286, 13438-13447. [CrossRef]

91. Prieto-Fernández, E.; Egia-Mendikute, L.; Bosch, A.; García del Río, A.; Jimenez-Lasheras, B.; Antoñana-Vildosola, A.; Lee, S.Y.; Palazon, A. Hypoxia Promotes Syndecan-3 Expression in the Tumor Microenvironment. Front. Immunol. 2020, 11, 2536. [CrossRef]

92. Silberman, A.; Goldman, O.; Assayag, O.B.; Jacob, A.; Rabinovich, S.; Adler, L.; Lee, J.S.; Keshet, R.; Sarver, A.; Frug, J.; et al. Acid-induced downregulation of ASS1 contributes to the maintenance of intracellular pH in cancer. Cancer Res. 2019, 79, 518-533. [CrossRef] [PubMed]

93. Walbrecq, G.; Lecha, O.; Gaigneaux, A.; Fougeras, M.R.; Philippidou, D.; Margue, C.; Nomigni, M.T.; Bernardin, F.; Dittmar, G.; Behrmann, I.; et al. Hypoxia-induced adaptations of mirnomes and proteomes in melanoma cells and their secreted extracellular vesicles. Cancers 2020, 12, 692. [CrossRef] [PubMed]

94. Zhao, J.; Shi, L.; Zeng, S.; Ma, C.; Xu, W.; Zhang, Z.; Liu, Q.; Zhang, P.; Sun, Y.; Xu, C. Importin-11 overexpression promotes the migration, invasion, and progression of bladder cancer associated with the deregulation of CDKN1A and THBS1. Urol. Oncol. Semin. Orig. Investig. 2018, 36, 311.e1-311.e13. [CrossRef] [PubMed] 
95. Guo, W.; Zhang, L.; Christopher, D.M.; Teng, Z.Q.; Fausett, S.R.; Liu, C.; George, O.L.; Klingensmith, J.; Jin, P.; Zhao, X. RNABinding Protein FXR2 Regulates Adult Hippocampal Neurogenesis by Reducing Noggin Expression. Neuron 2011, 70, 924-938. [CrossRef] [PubMed]

96. Majumder, M.; Johnson, R.H.; Palanisamy, V. Fragile X-related protein family: A double-edged sword in neurodevelopmental disorders and cancer. Crit. Rev. Biochem. Mol. Biol. 2020, 55, 409-424. [CrossRef] [PubMed]

97. Fan, Y.; Yue, J.; Xiao, M.; Han-Zhang, H.; Wang, Y.V.; Ma, C.; Deng, Z.; Li, Y.; Yu, Y.; Wang, X.; et al. FXR1 regulates transcription and is required for growth of human cancer cells with TP53/FXR2 homozygous deletion. Elife 2017, 6, e26129. [CrossRef]

98. Ashton, T.M.; Gillies McKenna, W.; Kunz-Schughart, L.A.; Higgins, G.S. Oxidative phosphorylation as an emerging target in cancer therapy. Clin. Cancer Res. 2018, 24, 2482-2490. [CrossRef]

99. Koch, A.; Ebert, E.V.; Seitz, T.; Dietrich, P.; Berneburg, M.; Bosserhoff, A.; Hellerbrand, C. Characterization of glycolysis-related gene expression in malignant melanoma. Pathol. Res. Pract. 2020, 216, 152752. [CrossRef]

100. Trojan, S.E.; Piwowar, M.; Ostrowska, B.; Laidler, P.; Kocemba-Pilarczyk, K.A. Analysis of malignant melanoma cell lines exposed to hypoxia reveals the importance of PFKFB4 overexpression for disease progression. Anticancer Res. 2018, 38, 6745-6752. [CrossRef]

101. Zhuo, M.; Gorgun, F.M.; Tyler, D.S.; Englander, E.W. Hypoxia potentiates the capacity of melanoma cells to evade cisplatin and doxorubicin cytotoxicity via glycolytic shift. FEBS Open Bio. 2020, 10, 789-801. [CrossRef]

102. Chang, S.; Yim, S.; Park, H. The cancer driver genes IDH1/2, JARID1C/KDM5C, and UTX/KDM6A: Crosstalk between histone demethylation and hypoxic reprogramming in cancer metabolism. Exp. Mol. Med. 2019, 51, 1-17. [CrossRef] [PubMed]

103. Pan, M.; Reid, M.A.; Lowman, X.H.; Kulkarni, R.P.; Tran, T.Q.; Liu, X.; Yang, Y.; Hernandez-Davies, J.E.; Rosales, K.K.; Li, H.; et al. Regional glutamine deficiency in tumours promotes dedifferentiation through inhibition of histone demethylation. Nat. Cell Biol. 2016, 18, 1090-1101. [CrossRef] [PubMed]

104. Filipp, F.V.; Scott, D.A.; Ronai, Z.A.; Osterman, A.L.; Smith, J.W. Reverse TCA cycle flux through isocitrate dehydrogenases 1 and 2 is required for lipogenesis in hypoxic melanoma cells. Pigment Cell Melanoma Res. 2012, 25, 375-383. [CrossRef] [PubMed]

105. Louphrasitthiphol, P.; Ledaki, I.; Chauhan, J.; Falletta, P.; Siddaway, R.; Buffa, F.M.; Mole, D.R.; Soga, T.; Goding, C.R. MITF controls the TCA cycle to modulate the melanoma hypoxia response. Pigment Cell Melanoma Res. 2019, 32, 792-808. [CrossRef]

106. Krzywinska, E.; Stockmann, C. Hypoxia, metabolism and immune cell function. Biomedicines 2018, 6, 56. [CrossRef]

107. Vito, A.; El-Sayes, N.; Mossman, K. Hypoxia-Driven Immune Escape in the Tumor Microenvironment. Cells $2020,9,992$. [CrossRef]

108. Durgeau, A.; Virk, Y.; Corgnac, S.; Mami-Chouaib, F. Recent advances in targeting CD8 T-cell immunity for more effective cancer immunotherapy. Front. Immunol. 2018, 9, 14. [CrossRef]

109. Manaster, Y.; Shipony, Z.; Hutzler, A.; Kolesnikov, M.; Avivi, C.; Shalmon, B.; Barshack, I.; Besser, M.J.; Feferman, T.; Shakhar, G. Reduced CTL motility and activity in avascular tumor areas. Cancer Immunol. Immunother. 2019, 68, 1287-1301. [CrossRef]

110. Marijt, K.A.; Sluijter, M.; Blijleven, L.; Tolmeijer, S.H.; Scheeren, F.A.; Van Der Burg, S.H.; Van Hall, T. Metabolic stress in cancer cells induces immune escape through a PI3K-dependent blockade of IFN $\gamma$ receptor signaling. J. Immunother. Cancer $2019,7,152$. [CrossRef]

111. Engel, C.; Brügmann, G.; Lambing, S.; Mühlenbeck, L.H.; Marx, S.; Hagen, C.; Horv, D.; Goldeck, M.; Ludwig, J.; Herzne, A.M.; et al. RIG-I Resists Hypoxia-Induced Immunosuppression and Dedifferentiation. Cancer Immunol. Res. 2017, 5, 455-467. [CrossRef] [PubMed]

112. Hatfield, S.M.; Kjaergaard, J.; Lukashev, D.; Belikoff, B.; Schreiber, T.H.; Sethumadhavan, S.; Abbott, R.; Philbrook, P.; Thayer, M.; Shujia, D.; et al. Systemic oxygenation weakens the hypoxia and hypoxia inducible factor $1 \alpha$-dependent and extracellular adenosine-mediated tumor protection. J. Mol. Med. 2014, 92, 1283-1292. [CrossRef]

113. Wen, A.Y.; Sakamoto, K.M.; Miller, L.S. The Role of the Transcription Factor CREB in Immune Function. J. Immunol. 2010, 185, 6413-6419. [CrossRef]

114. Cekic, C.; Day, Y.J.; Sag, D.; Linden, J. Myeloid expression of adenosine a2A receptor suppresses T and NK cell responses in the solid tumor microenvironment. Cancer Res. 2014, 74, 7250-7259. [CrossRef]

115. Vigano, S.; Alatzoglou, D.; Irving, M.; Ménétrier-Caux, C.; Caux, C.; Romero, P.; Coukos, G. Targeting adenosine in cancer immunotherapy to enhance T-Cell function. Front. Immunol. 2019, 10, 925. [CrossRef]

116. Tittarelli, A.; Janji, B.; Van Moer, K.; Noman, M.Z.; Chouaib, S. The selective degradation of synaptic connexin 43 protein by hypoxia-induced autophagy impairs natural killer cell-mediated tumor cell killing. J. Biol. Chem. 2015, 290, 23670-23679. [CrossRef]

117. Noman, M.Z.; Buart, S.; Romero, P.; Ketari, S.; Janji, B.; Mari, B.; Mami-Chouaib, F.; Chouaib, S. Hypoxia-inducible miR210 regulates the susceptibility of tumor cells to lysis by cytotoxic T cells. Cancer Res. 2012, 72, 4629-4641. [CrossRef] [PubMed]

118. Romano, G.; Kwong, L.N. MiRNAs, melanoma and microenvironment: An intricate network. Int. J. Mol. Sci. 2017, 18, 2354. [CrossRef] [PubMed]

119. Kajiwara, T.; Tanaka, T.; Kukita, K.; Kutomi, G.; Saito, K.; Okuya, K.; Takaya, A.; Kochin, V.; Kanaseki, T.; Tsukahara, T.; et al. Hypoxia augments MHC class I antigen presentation via facilitation of ERO1- $\alpha$-mediated oxidative folding in murine tumor cells. Eur. J. Immunol. 2016, 46, 2842-2851. [CrossRef] [PubMed]

120. Gropper, Y.; Feferman, T.; Shalit, T.; Salame, T.M.; Porat, Z.; Shakhar, G. Culturing CTLs under Hypoxic Conditions Enhances Their Cytolysis and Improves Their Anti-tumor Function. Cell Rep. 2017, 20, 2547-2555. [CrossRef] [PubMed] 
121. Calvani, M.; Bruno, G.; Dal Monte, M.; Nassini, R.; Fontani, F.; Casini, A.; Cavallini, L.; Becatti, M.; Bianchini, F.; De Logu, F.; et al. ß3-Adrenoceptor as a potential immuno-suppressor agent in melanoma. Br. J. Pharmacol. 2019, 176, 2509-2524. [CrossRef]

122. Bronkhorst, I.H.G.; Jehs, T.M.L.; Dijkgraaf, E.M.; Luyten, G.P.M.; Van Der Velden, P.A.; Van Der Burg, S.H.; Jager, M.J. Effect of hypoxic stress on migration and characteristics of monocytes in uveal melanoma. JAMA Ophthalmol. 2014, 132, 614-621. [CrossRef] [PubMed]

123. Campillo, N.; Falcones, B.; Otero, J.; Colina, R.; Gozal, D.; Navajas, D.; Farré, R.; Almendros, I. Differential oxygenation in tumor microenvironment modulates macrophage and cancer cell crosstalk: Novel experimental settingand proof of concept. Front. Oncol. 2019, 9, 43. [CrossRef] [PubMed]

124. Huber, R.; Meier, B.; Otsuka, A.; Fenini, G.; Satoh, T.; Gehrke, S.; Widmer, D.; Levesque, M.P.; Mangana, J.; Kerl, K.; et al. Tumour hypoxia promotes melanoma growth and metastasis via High Mobility Group Box-1 and M2-like macrophages. Sci. Rep. 2016, 6, 29914. [CrossRef] [PubMed]

125. Yang, J.B.; Zhao, Z.B.; Liu, Q.Z.; Hu, T.D.; Long, J.; Yan, K.; Lian, Z.X. FoxO1 is a regulator of MHC-II expression and anti-tumor effect of tumor-associated macrophages. Oncogene 2018, 37, 1192-1204. [CrossRef] [PubMed]

126. Gaustad, J.-V.; Simonsen, T.G.; Andersen, L.M.K.; Rofstad, E.K. Vascular abnormalities and development of hypoxia in microscopic melanoma xenografts. J. Transl. Med. 2017, 15, 241. [CrossRef] [PubMed]

127. Ng, W.L.; Huang, Q.; Liu, X.; Zimmerman, M.; Li, F.; Li, C.Y. Molecular mechanisms involved in tumor repopulation after radiotherapy. Transl. Cancer Res. 2013, 2, 442-448. [CrossRef]

128. Wittgen, H.G.M.; Van Kempen, L.C.L.T. Reactive oxygen species in melanoma and its therapeutic implications. Melanoma Res. 2007, 17, 400-409. [CrossRef] [PubMed]

129. Brown, J.M.; Wilson, W.R. Exploiting tumour hypoxia in cancer treatment. Nat. Rev. Cancer 2004, 4, 437-447. [CrossRef]

130. Jour, G.; Ivan, D.; Aung, P.P. Angiogenesis in melanoma: An update with a focus on current targeted therapies. J. Clin. Pathol. 2016, 69, 472-483. [CrossRef]

131. Collet, G.; Lamerant-Fayel, N.; Tertil, M.; El Hafny-Rahbi, B.; Stepniewski, J.; Guichard, A.; Foucault-Collet, A.; Klimkiewicz, K.; Petoud, S.; Matejuk, A.; et al. Hypoxia-regulated overexpression of soluble VEGFR2 controls angiogenesis and inhibits tumor growth. Mol. Cancer Ther. 2013, 13, 165-178. [CrossRef]

132. Roda, J.M.; Sumner, L.A.; Evans, R.; Phillips, G.S.; Marsh, C.B.; Eubank, T.D. Hypoxia-Inducible Factor-2 $\alpha$ Regulates GM-CSFDerived Soluble Vascular Endothelial Growth Factor Receptor 1 Production from Macrophages and Inhibits Tumor Growth and Angiogenesis. J. Immunol. 2011, 187, 1970-1976. [CrossRef]

133. Agrawal, V.; Maharjan, S.; Kim, K.; Kim, N.J.; Son, J.; Lee, K.; Choi, H.J.; Rho, S.S.; Ahn, S.; Won, M.H.; et al. Direct endothelial junction restoration results in significant tumor vascular normalization and metastasis inhibition in mice. Oncotarget 2014, 5, 2761-2777. [CrossRef]

134. Martí-Díaz, R.; Montenegro, M.F.; Cabezas-Herrera, J.; Goding, C.R.; Rodríguez-López, J.N.; Sánchez-del-Campo, L. Acriflavine, a Potent Inhibitor of HIF-1 $\alpha$, Disturbs Glucose Metabolism and Suppresses ATF4-Protective Pathways in Melanoma under Non-Hypoxic Conditions. Cancers 2020, 13, 102. [CrossRef] [PubMed]

135. Zhao, H.; Jiang, H.; Li, Z.; Yafei, Z.; Liu, Y.; Zhou, S.; Xiao, Y.; Xie, C.; Zhou, F.; Zhou, Y. 2-Methoxyestradiol enhances radiosensitivity in radioresistant melanoma MDA-MB-435R cells by regulating glycolysis via HIF-1 $\alpha /$ PDK1 axis. Int. J. Oncol. 2017, 50, 1531-1540. [CrossRef] [PubMed]

136. Patra, K.; Jana, S.; Sarkar, A.; Mandal, D.P.; Bhattacharjee, S. The inhibition of hypoxia-induced angiogenesis and metastasis by cinnamaldehyde is mediated by decreasing HIF-1 $\alpha$ protein synthesis via PI3K/Akt pathway. BioFactors 2019, 45, 401-415. [CrossRef] [PubMed]

137. Scharping, N.E.; Menk, A.V.; Whetstone, R.D.; Zeng, X.; Delgoffe, G.M. Efficacy of PD-1 blockade is potentiated by metformininduced reduction of tumor hypoxia. Cancer Immunol. Res. 2017, 5, 9-16. [CrossRef] [PubMed]

138. Jiang, M.S.; Yin, X.Y.; Qin, B.; Xuan, S.Y.; Yuan, X.L.; Yin, H.; Zhu, C.; Li, X.; Yang, J.; Du, Y.Z.; et al. Inhibiting Hypoxia and Chemotherapy-Induced Cancer Cell Metastasis under a Valid Therapeutic Effect by an Assistance of Biomimetic Oxygen Delivery. Mol. Pharm. 2019, 16, 4530-4541. [CrossRef]

139. Hei, Y.; Teng, B.; Zeng, Z.; Zhang, S.; Li, Q.; Pan, J.; Luo, Z.; Xiong, C.; Wei, S. Multifunctional immunoliposomes combining catalase and PD-L1 antibodies overcome tumor hypoxia and enhance immunotherapeutic effects against melanoma. Int. J. Nanomed. 2020, 15, 1677-1691. [CrossRef]

140. Zou, M.-Z.; Liu, W.-L.; Li, C.-X.; Zheng, D.-W.; Zeng, J.-Y.; Gao, F.; Ye, J.-J.; Zhang, X.-Z. A Multifunctional Biomimetic Nanoplatform for Relieving Hypoxia to Enhance Chemotherapy and Inhibit the PD-1/PD-L1 Axis. Small 2018, 14, 1801120. [CrossRef]

141. Zhou, J.; Geng, S.; Ye, W.; Wang, Q.; Lou, R.; Yin, Q.; Du, B.; Yao, H. ROS-boosted photodynamic therapy against metastatic melanoma by inhibiting the activity of antioxidase and oxygen-producing nano-dopants. Pharmacol. Res. 2020, $158,104885$. [CrossRef]

142. Bagati, A.; Hutcherson, T.C.; Koch, Z.; Pechette, J.; Dianat, H.; Higley, C.; Chiu, L.; Song, Y.; Shah, J.; Chazen, E.; et al. Novel combination therapy for melanoma induces apoptosis via a gap junction positive feedback mechanism. Oncotarget 2020, 11, 3443-3458. [CrossRef] [PubMed] 
143. Liu, Q.; Sun, J.D.; Wang, J.; Ahluwalia, D.; Baker, A.F.; Cranmer, L.D.; Ferraro, D.; Wang, Y.; Duan, J.X.; Ammons, W.S.; et al. TH-302, a hypoxia-activated prodrug with broad in vivo preclinical combination therapy efficacy: Optimization of dosing regimens and schedules. Cancer Chemother. Pharmacol. 2012, 69, 1487-1498. [CrossRef] [PubMed]

144. Liu, Z.; Liu, X.; Cao, W.; Hua, Z.-C. Tumor-specifically hypoxia-induced therapy of SPRY1/2 displayed differential therapeutic efficacy for melanoma. Am. J. Cancer Res. 2015, 5, 792-801. [PubMed]

145. Feng, X.; He, P.; Zeng, C.; Li, Y.H.; Das, S.K.; Li, B.; Yang, H.F.; Du, Y. Novel insights into the role of Clostridium novyi-NT related combination bacteriolytic therapy in solid tumors. Oncol. Lett. 2021, 21, 110. [CrossRef]

146. Yura, Y.; Chong, B.S.H.; Johnson, R.D.; Watanabe, Y.; Tsukahara, Y.; Ferran, B.; Murdoch, C.E.; Behring, J.B.; McComb, M.E.; Costello, C.E.; et al. Endothelial cell-specific redox gene modulation inhibits angiogenesis but promotes B16F0 tumor growth in mice. FASEB J. 2019, 33, 14147-14158. [CrossRef] [PubMed]

147. Dong, L.; You, S.; Zhang, Q.; Osuka, S.; Devi, N.S.; Kaluz, S.; Ferguson, J.H.; Yang, H.; Chen, G.; Wang, B.; et al. Arylsulfonamide 64B inhibits hypoxia/HIF-induced expression of c-Met and CXCR4 and reduces primary tumor growth and metastasis of uveal melanoma. Clin. Cancer Res. 2019, 25, 2206-2218. [CrossRef] [PubMed]

148. Zhu, C.; Guo, X.; Luo, L.; Wu, Z.; Luo, Z.; Jiang, M.; Zhang, J.; Qin, B.; Shi, Y.; Lou, Y.; et al. Extremely Effective Chemoradiotherapy by Inducing Immunogenic Cell Death and Radio-Triggered Drug Release under Hypoxia Alleviation. ACS Appl. Mater. Interfaces 2019, 11, 46536-46547. [CrossRef]

149. Liu, S.; Tetzlaff, M.T.; Wang, T.; Chen, X.; Yang, R.; Kumar, S.M.; Vultur, A.; Li, P.; Martin, J.S.; Herlyn, M.; et al. Hypoxia-activated prodrug enhances therapeutic effect of sunitinib in melanoma. Oncotarget 2017, 8, 115140-115152. [CrossRef] [PubMed]

150. Webb, B.A.; Chimenti, M.; Jacobson, M.P.; Barber, D.L. Dysregulated pH: A perfect storm for cancer progression. Nat. Rev. Cancer 2011, 11, 671-677. [CrossRef] [PubMed]

151. Böhme, I.; Bosserhoff, A.K. Acidic tumor microenvironment in human melanoma. Pigment. Cell Melanoma Res. 2016, 29 , 508-523. [CrossRef]

152. Tannock, I.F.; Rotin, D. Acid pH in Tumors and Its Potential for Therapeutic Exploitation. Cancer Res. 1989, 49, 4373-4384.

153. Gatenby, R.A.; Gillies, R.J. Why do cancers have high aerobic glycolysis? Nat. Rev. Cancer 2004, 4, 891-899. [CrossRef]

154. Koch, A.; Schwab, A. Cutaneous pH landscape as a facilitator of melanoma initiation and progression. Acta Physiol. 2019, 225, e13105. [CrossRef] [PubMed]

155. Kato, Y.; Ozawa, S.; Miyamoto, C.; Maehata, Y.; Suzuki, A.; Maeda, T.; Baba, Y. Acidic extracellular microenvironment and cancer. Cancer Cell Int. 2013, 13, 89. [CrossRef] [PubMed]

156. Wang, T.; Liu, G.; Wang, R. The intercellular metabolic interplay between tumor and immune cells. Front. Immunol. 2014, 5, 358. [CrossRef] [PubMed]

157. Palmer, S.R.; Erickson, L.A.; Ichetovkin, I.; Knauer, D.J.; Markovic, S.N. Circulating serologic and molecular biomarkers in malignant melanoma. Mayo Clin. Proc. 2011, 86, 981-990. [CrossRef] [PubMed]

158. Hulikova, A.; Black, N.; Hsia, L.T.; Wilding, J.; Bodmer, W.F.; Swietach, P. Stromal uptake and transmission of acid is a pathway for venting cancer cell-generated acid. Proc. Natl. Acad. Sci. USA 2016, 113, E5344-E5353. [CrossRef] [PubMed]

159. La Shu, S.; Yang, Y.; Allen, C.L.; Maguire, O.; Minderman, H.; Sen, A.; Ciesielski, M.J.; Collins, K.A.; Bush, P.J.; Singh, P.; et al. Metabolic reprogramming of stromal fibroblasts by melanoma exosome microRNA favours a pre-metastatic microenvironment. Sci. Rep. 2018, 8, 12905. [CrossRef]

160. Liu, Y.; Huo, Y.; Wang, D.; Tai, Y.; Li, J.; Pang, D.; Zhang, Y.; Zhao, W.; Du, N.; Huang, Y. MiR-216a-5p/Hexokinase 2 axis regulates uveal melanoma growth through modulation of Warburg effect. Biochem. Biophys. Res. Commun. 2018, 501, 885-892. [CrossRef]

161. Yang, X.; Zhu, X.; Yan, Z.; Li, C.; Zhao, H.; Ma, L.; Zhang, D.; Liu, J.; Liu, Z.; Du, N.; et al. miR-489-3p/SIX1 Axis Regulates Melanoma Proliferation and Glycolytic Potential. Mol. Ther. Oncolytics 2020, 16, 30-40. [CrossRef] [PubMed]

162. Yang, X.; Zhao, H.; Yang, J.; Ma, Y.; Liu, Z.; Li, C.; Wang, T.; Yan, Z.; Du, N. MiR-150-5p regulates melanoma proliferation, invasion and metastasis via SIX1-mediated Warburg Effect. Biochem. Biophys. Res. Commun. 2019, 515, 85-91. [CrossRef] [PubMed]

163. Vahle, A.K.; Domikowsky, B.; Schwöppe, C.; Krähling, H.; Mally, S.; Schäfers, M.; Hermann, S.; Shahin, V.; Haier, J.; Schwab, A.; et al. Extracellular matrix composition and interstitial pH modulate NHE1-mediated melanoma cell motility. Int. J. Oncol. 2014, 44, 78-90. [CrossRef] [PubMed]

164. Karki, P.; Li, X.; Schrama, D.; Fliegel, L. B-Raf associates with and activates the NHE1 isoform of the Na +/H+ exchanger. J. Biol. Chem. 2011, 286, 13096-13105. [CrossRef]

165. Ferretta, A.; Maida, I.; Guida, S.; Azzariti, A.; Porcelli, L.; Tommasi, S.; Zanna, P.; Cocco, T.; Guida, M.; Guida, G. New insight into the role of metabolic reprogramming in melanoma cells harboring BRAF mutations. Biochim. Biophys. Acta Mol. Cell Res. 2016, 1863, 2710-2718. [CrossRef] [PubMed]

166. Wahl, M.L.; Owen, J.A.; Burd, R.; Herlands, R.A.; Nogami, S.S.; Rodeck, U.; Berd, D.; Leeper, D.B.; Owen, C.S. Regulation of intracellular $\mathrm{pH}$ in human melanoma: Potential therapeutic implications. Mol. Cancer Ther. 2002, 1, 617-628.

167. Böhme, I.; Bosserhoff, A. Extracellular acidosis triggers a senescence-like phenotype in human melanoma cells. Pigment. Cell Melanoma Res. 2020, 33, 41-51. [CrossRef] [PubMed]

168. Romero-Garcia, S.; Moreno-Altamirano, M.M.B.; Prado-Garcia, H.; Sánchez-García, F.J. Lactate contribution to the tumor microenvironment: Mechanisms, effects on immune cells and therapeutic relevance. Front. Immunol. 2016, 7, 52. [CrossRef] [PubMed] 
169. Rofstad, E.K.; Mathiesen, B.; Kindem, K.; Galappathi, K. Acidic extracellular pH promotes experimental metastasis of human melanoma cells in athymic nude mice. Cancer Res. 2006, 66, 6699-6707. [CrossRef]

170. Martínez-Zaguilán, R.; Seftor, E.A.; Seftor, R.E.B.; Chu, Y.W.; Gillies, R.J.; Hendrix, M.J.C. Acidic pH enhances the invasive behavior of human melanoma cells. Clin. Exp. Metastasis 1996, 14, 176-186. [CrossRef]

171. Pinheiro, C.; Miranda-Gonçalves, V.; Longatto-Filho, A.; Vicente, A.L.S.A.; Berardinelli, G.N.; Scapulatempo-Neto, C.; Costa, R.F.A.; Viana, C.R.; Reis, R.M.; Baltazar, F.; et al. The metabolic microenvironment of melanomas: Prognostic value of MCT1 and MCT4. Cell Cycle 2016, 15, 1462-1470. [CrossRef]

172. Goda, N.; Kanai, M. Hypoxia-inducible factors and their roles in energy metabolism. Int. J. Hematol. 2012, 95, 457-463. [CrossRef] [PubMed]

173. Wykoff, C.C.; Beasley, N.J.P.; Watson, P.H.; Turner, K.J.; Pastorek, J.; Sibtain, A.; Wilson, G.D.; Turley, H.; Talks, K.L.; Maxwell, P.H.; et al. Hypoxia-inducible expression of tumor-associated carbonic anhydrases. Cancer Res. 2000, 60, 7075-7083. [PubMed]

174. Brahimi-Horn, M.C.; Pouysségur, J. Hypoxia in cancer cell metabolism and pH regulation. Essays Biochem. 2007, 43, 165-178. [CrossRef] [PubMed]

175. Chafe, S.C.; McDonald, P.C.; Saberi, S.; Nemirovsky, O.; Venkateswaran, G.; Burugu, S.; Gao, D.; Delaidelli, A.; Kyle, A.H.; Baker, J.H.E.; et al. Targeting hypoxia-induced carbonic anhydrase IX enhances immune-checkpoint blockade locally and systemically. Cancer Immunol. Res. 2019, 7, 1064-1078. [CrossRef]

176. Giuntini, G.; Monaci, S.; Cau, Y.; Mori, M.; Naldini, A.; Carraro, F. Inhibition of Melanoma Cell Migration and Invasion Targeting the Hypoxic Tumor Associated CAXII. Cancers 2020, 12, 3018. [CrossRef] [PubMed]

177. Andreucci, E.; Peppicelli, S.; Carta, F.; Brisotto, G.; Biscontin, E.; Ruzzolini, J.; Bianchini, F.; Biagioni, A.; Supuran, C.T.; Calorini, L. Carbonic anhydrase IX inhibition affects viability of cancer cells adapted to extracellular acidosis. J. Mol. Med. 2017, 95, 1341-1353. [CrossRef]

178. Moellering, R.E.; Black, K.C.; Krishnamurty, C.; Baggett, B.K.; Stafford, P.; Rain, M.; Gatenby, R.A.; Gillies, R.J. Acid treatment of melanoma cells selects for invasive phenotypes. Clin. Exp. Metastasis 2008, 25, 411-425. [CrossRef]

179. Marino, M.L.; Pellegrini, P.; Di Lernia, G.; Djavaheri-Mergny, M.; Brnjic, S.; Zhang, X.; Hägg, M.; Linder, S.; Fais, S.; Codogno, P.; et al. Autophagy is a protective mechanism for human melanoma cells under acidic stress. J. Biol. Chem. 2012, 287, 30664-30676. [CrossRef]

180. Matsuo, T.; Sadzuka, Y. Extracellular acidification by lactic acid suppresses glucose deprivation-induced cell death and autophagy in B16 melanoma cells. Biochem. Biophys. Res. Commun. 2018, 496, 1357-1361. [CrossRef]

181. Peppicelli, S.; Bianchini, F.; Torre, E.; Calorini, L. Contribution of acidic melanoma cells undergoing epithelial-to-mesenchymal transition to aggressiveness of non-acidic melanoma cells. Clin. Exp. Metastasis 2014, 31, 423-433. [CrossRef]

182. Andreucci, E.; Peppicelli, S.; Ruzzolini, J.; Bianchini, F.; Biagioni, A.; Papucci, L.; Magnelli, L.; Mazzanti, B.; Stecca, B.; Calorini, L. The acidic tumor microenvironment drives a stem-like phenotype in melanoma cells. J. Mol. Med. 2020, 98, 1431-1446. [CrossRef] [PubMed]

183. Krähling, H.; Mally, S.; Eble, J.A.; Noël, J.; Schwab, A.; Stock, C. The glycocalyx maintains a cell surface pH nanoenvironment crucial for integrin-mediated migration of human melanoma cells. Pflugers Arch. Eur. J. Physiol. 2009, 458, 1069-1083. [CrossRef] [PubMed]

184. Paradise, R.K.; Lauffenburger, D.A.; van Vliet, K.J. Acidic extracellular pH promotes activation of integrin $\alpha \mathrm{v} \beta 3$. PLoS ONE 2011, 6, e15746. [CrossRef] [PubMed]

185. Stock, C.; Gassner, B.; Hauck, C.R.; Arnold, H.; Mally, S.; Eble, J.A.; Dieterich, P.; Schwab, A. Migration of human melanoma cells depends on extracellular $\mathrm{pH}$ and $\mathrm{Na}+\mathrm{H}+$ exchange. J. Physiol. 2005, 567, 225-238. [CrossRef] [PubMed]

186. Serpa, J. Tumor Microenvironment; Siemann, D.W., Ed.; John Wiley \& Sons, Ltd.: Hoboken, NJ, USA, $2020 ;$ ISBN 9780470749968.

187. Ludwig, F.T.; Schwab, A.; Stock, C. The Na+/H+-exchanger (NHE1) generates pH nanodomains at focal adhesions. J. Cell. Physiol. 2013, 228, 1351-1358. [CrossRef] [PubMed]

188. Hofschroër, V.; Koch, K.A.; Ludwig, F.T.; Friedl, P.; Oberleithner, H.; Stock, C.; Schwab, A. Extracellular protonation modulates cell-cell interaction mechanics and tissue invasion in human melanoma cells. Sci. Rep. 2017, 7, 42369. [CrossRef] [PubMed]

189. Stüwe, L.; Müller, M.; Fabian, A.; Waning, J.; Mally, S.; Noël, J.; Schwab, A.; Stock, C. pH dependence of melanoma cell migration: Protons extruded by NHE1 dominate protons of the bulk solution. J. Physiol. 2007, 585, 351-360. [CrossRef]

190. Estrella, V.; Chen, T.; Lloyd, M.; Wojtkowiak, J.; Cornnell, H.H.; Ibrahim-Hashim, A.; Bailey, K.; Balagurunathan, Y.; Rothberg, J.M.; Sloane, B.F.; et al. Acidity generated by the tumor microenvironment drives local invasion. Cancer Res. 2013, 73, 1524-1535. [CrossRef]

191. Kato, Y.; Lambert, C.A.; Colige, A.C.; Mineur, P.; Noël, A.; Frankenne, F.; Foidart, J.M.; Baba, M.; Hata, R.I.; Miyazaki, K.; et al. Acidic extracellular $\mathrm{pH}$ induces matrix metalloproteinase-9 expression in mouse metastatic melanoma cells through the phospholipase D-mitogen-activated protein kinase signaling. J. Biol. Chem. 2005, 280, 10938-10944. [CrossRef]

192. Sonveaux, P.; Copetti, T.; de Saedeleer, C.J.; Végran, F.; Verrax, J.; Kennedy, K.M.; Moon, E.J.; Dhup, S.; Danhier, P.; Frérart, F.; et al. Targeting the lactate transporter MCT1 in endothelial cells inhibits lactate-induced HIF-1 activation and tumor angiogenesis. PLoS ONE 2012, 7, e33418. [CrossRef]

193. Mahoney, B.P.; Raghunand, N.; Baggett, B.; Gillies, R.J. Tumor acidity, ion trapping and chemotherapeutics: I. Acid pH affects the distribution of chemotherapeutic agents in vitro. Biochem. Pharmacol. 2003, 66, 1207-1218. [CrossRef] 
194. Ruzzolini, J.; Peppicelli, S.; Andreucci, E.; Bianchini, F.; Margheri, F.; Laurenzana, A.; Fibbi, G.; Pimpinelli, N.; Calorini, L. Everolimus selectively targets vemurafenib resistant BRAFV600E melanoma cells adapted to low pH. Cancer Lett. 2017, 408, 43-54. [CrossRef]

195. Leikam, C.; Hufnagel, A.L.; Otto, C.; Murphy, D.J.; Mühling, B.; Kneitz, S.; Nanda, I.; Schmid, M.; Wagner, T.U.; Haferkamp, S.; et al. In vitro evidence for senescent multinucleated melanocytes as a source for tumor-initiating cells. Cell Death Dis. 2015, 6, e1711. [CrossRef]

196. Mccarty, M.F.; Whitaker, J. Manipulating tumor acidification as a cancer treatment strategy. Altern. Med. Rev. 2010, 15, $264-272$.

197. Lardner, A. The effects of extracellular pH on immune function. J. Leukoc. Biol. 2001, 69, 522-530. [CrossRef] [PubMed]

198. Fischer, K.; Hoffmann, P.; Voelkl, S.; Meidenbauer, N.; Ammer, J.; Edinger, M.; Gottfried, E.; Schwarz, S.; Rothe, G.; Hoves, S.; et al. Inhibitory effect of tumor cell-derived lactic acid on human T cells. Blood 2007, 109, 3812-3819. [CrossRef]

199. Feder-Mengus, C.; Ghosh, S.; Weber, W.P.; Wyler, S.; Zajac, P.; Terracciano, L.; Oertli, D.; Heberer, M.; Martin, I.; Spagnoli, G.C.; et al. Multiple mechanisms underlie defective recognition of melanoma cells cultured in three-dimensional architectures by antigen-specific cytotoxic T lymphocytes. Br. J. Cancer 2007, 96, 1072-1082. [CrossRef] [PubMed]

200. Bohn, T.; Rapp, S.; Luther, N.; Klein, M.; Bruehl, T.J.; Kojima, N.; Aranda Lopez, P.; Hahlbrock, J.; Muth, S.; Endo, S.; et al. Tumor immunoevasion via acidosis-dependent induction of regulatory tumor-associated macrophages. Nat. Immunol. 2018, 19, 1319-1329. [CrossRef]

201. Pilon-Thomas, S.; Kodumudi, K.N.; El-Kenawi, A.E.; Russell, S.; Weber, A.M.; Luddy, K.; Damaghi, M.; Wojtkowiak, J.W.; Mulé, J.J.; Ibrahim-Hashim, A.; et al. Neutralization of tumor acidity improves antitumor responses to immunotherapy. Cancer Res. 2016, 76, 1381-1390. [CrossRef] [PubMed]

202. Uhl, F.M.; Chen, S.; O’Sullivan, D.; Edwards-Hicks, J.; Richter, G.; Haring, E.; Andrieux, G.; Halbach, S.; Apostolova, P.; Büscher, J.; et al. Metabolic reprogramming of donor T cells enhances graft-versus-leukemia effects in mice and humans. Sci. Transl. Med. 2020, 12, eabb8969. [CrossRef] [PubMed]

203. Gullotti, E.; Yeo, Y. Extracellularly activated nanocarriers: A new paradigm of tumor targeted drug delivery. Mol. Pharm. 2009, 6, 1041-1051. [CrossRef] [PubMed]

204. De Milito, A.; Canese, R.; Marino, M.L.; Borghi, M.; Iero, M.; Villa, A.; Venturi, G.; Lozupone, F.; Iessi, E.; Logozzi, M.; et al. $\mathrm{PH}$-dependent antitumor activity of proton pump inhibitors against human melanoma is mediated by inhibition of tumor acidity. Int. J. Cancer 2010, 127, 207-219. [CrossRef] [PubMed]

205. Luciani, F.; Spada, M.; De Milito, A.; Molinari, A.; Rivoltini, L.; Montinaro, A.; Marra, M.; Lugini, L.; Logozzi, M.; Lozupone, F; et al. Effect of proton pump inhibitor pretreatment on resistance of solid tumors to cytotoxic drugs. J. Natl. Cancer Inst. 2004, 96, 1702-1713. [CrossRef] [PubMed] 